\title{
The putative lissamphibian stem-group: phylogeny and evolution of the dissorophoid temnospondyls
}

\author{
Rainer R. Schoch \\ Staatliches Museum für Naturkunde, Rosenstein 1, D-70191 Stuttgart, Germany 〈rainer.schoch@smns-bw.de〉
}

\begin{abstract}
Dissorophoid temnospondyls are widely considered to have given rise to some or all modern amphibians (Lissamphibia), but their ingroup relationships still bear major unresolved questions. An inclusive phylogenetic analysis of dissorophoids gives new insights into the large-scale topology of relationships. Based on a TNT 1.5 analysis (33 taxa, 108 characters), the enigmatic taxon Perryella is found to nest just outside Dissorophoidea (phylogenetic defintion), but shares a range of synapomorphies with this clade. The dissorophoids proper are found to encompass a first dichotomy between the largely paedomorphic Micromelerpetidae and all other taxa (Xerodromes). Within the latter, there is a basal dichotomy between the large, heavily ossified Olsoniformes (Dissorophidae + Trematopidae) and the small salamander-like Amphibamiformes (new taxon), which include four clades: (1) Micropholidae (Tersomius, Pasawioops, Micropholis); (2) Amphibamidae sensu stricto (Doleserpeton, Amphibamus); (3) Branchiosauridae (Branchiosaurus, Apateon, Leptorophus, Schoenfelderpeton); and (4) Lissamphibia. The genera Platyrhinops and Eoscopus are here found to nest at the base of Amphibamiformes. Represented by their basal-most stem-taxa (Triadobatrachus, Karaurus, Eocaecilia), lissamphibians nest with Gerobatrachus rather than Amphibamidae, as repeatedly found by former analyses.
\end{abstract}

UUID: http://zoobank.org/dadf36db-e003-4af7-bfa7-44d79bc04450

\section{Introduction}

Modern amphibians and their ancient relatives could hardly be more distinct in size, morphology, and ecological features. Whereas the three extant clades (frogs, salamanders, and caecilians) are generally small creatures with feeble skeletons, most of which feed on small invertebrates, their likely stemgroup, Paleozoic temnospondyls, encompasses 1-2 m long, heavily ossified predators. The evolutionary transition between the Paleozoic giants and the dwarfed modern forms has long been sought among the Dissorophoidea, a speciose clade of mainly terrestrial and presumably insect-eating CarboniferousTriassic temnospondyls that were usually smaller and had lessmassive skeletons than their fish-eating fellows (Watson, 1940; Romer, 1947; Reig, 1964), but alternative scenarios are still debated (Laurin and Reisz, 1997; Marjanovic and Laurin, 2008, 2009, 2013; Pardo et al., 2017). In recent time, new important stem-taxa were discovered (Bolt, 1969; Anderson et al., 2008a, b), which have made the origin at least of batrachians from within temnospondyls more likely and put the dissorophoids into focus of rigorous phylogenetic research (Milner, 1988, 1993; Trueb and Cloutier, 1991; Schoch and Milner, 2004; Ruta and Coates, 2007; Anderson, 2008; Fröbisch and Schoch, 2009a; Sigurdsen and Green, 2011; Maddin et al., 2012; Pérez Ben et al., 2018).

Dissorophoids themselves were only slowly recognized as a clade, because they fall into several highly distinct groups: (1) the $\sim 50 \mathrm{~cm}$ long, heavily built olsoniforms, comprising the monophyletic armoured Dissorophidae and the Trematopidae (Carroll, 1964; Berman et al., 1985; Dilkes, 1990; Reisz et al., 2009; Schoch, 2012); (2) the 10-20 cm long terrestrial Amphibamidae (Bolt, 1969; Daly, 1994; Schoch and Rubidge, 2005; Anderson et al., 2008b; Fröbisch and Reisz, 2008); (3) the 10$30 \mathrm{~cm}$ long aquatic gill-bearing Micromelerpetidae (Boy, 1972, 1995, 2002a, b; Werneburg, 1991, 1994; Witzmann and Pfretzschner, 2003); and finally (4) the larval-neotenic, gillbearing, up to $15 \mathrm{~cm}$ long Branchiosauridae (Boy, 1972, 1978, 1987; Werneburg, 1986, 1987, 1991, 2001; Schoch, 1992; Schoch and Milner, 2008). Although each of these groups has been hypothesized as a clade, an inclusive test of all of these hypotheses on a broader range of dissorophoid taxa has yet to be conducted.

The first dissorophoid skeleton discovered was that of a poorly preserved branchiosaurid from the lower Permian of Münsterappel in Germany, reported by Meyer (1848) as Apateon pedestris. This superficially salamander-like branchiosaurid was soon complemented by more frog-like skeletons from Pennsylvanian rocks from from Mazon Creek, Illinois, which were referred to as Pelion (Amphibamus) grandiceps (Wyman, 1858; Cope, 1865). After Moodie (1909, 1916), Romer (1930), and Steen $(1931,1938)$ had reported a range of similar taxa from additional Pennsylvanian deposits in the United States and Czech Republic, Watson (1940) wrote a review paper on the origin of anurans in which he sought the ancestry of frogs among amphibamids, notably the tiny, lightly built Amphibamus grandiceps Cope, 1865. The enlarged squamosal embayment (otic notch) of 
these taxa was given particular attention, as were the delicate stapes and the reduced nature of some dermal bones. These of course were features long known by students of temnospondyls to be shared with anurans, as exemplified by Quenstedt's (1850, p. 14) exclamation "true frog ears!" (German "wahre Froschohren") upon his discovery of the otic notch in the large capitosauroid temnospondyl Cyclotosaurus.

Almost three decades after Watson, Bolt (1969) reported the tiny amphibamid Doleserpeton annectens, phylogenetically the sister taxon to Amphibamus, but with two additional characters then unknown from any other temnospondyl: pedicellate teeth and cylindrical pleurocentra in the trunk vertebrae (Bolt, 1977). This was an important step forward because the cylindrical pleurocentra had long been considered a major argument against a temnospondyl relationship of lissamphibians, later upheld by Gardiner (1983) who argued for a close relationship among aïstopods, nectrideans, and lissamphibians on this basis. This was one reason why lepospondyls had been seen as the most plausible stem-group of extant amphibians, especially salamanders and caecilians (Romer, 1945; Schmalhausen, 1968; Carroll and Currie, 1975; Carroll and Holmes, 1980). However, this diphyletic hypothesis (temnospondyl anurans versus leopospondyl salamanders and caecilians) was never consistent in that anurans share the cylindrical vertebrae with other lissamphibians, but were nevertheless regarded temnospondyl descendants by most authors (Danto et al., 2016).

Later, Bolt (1977) discovered pedicely also in Amphibamus, but not Platyrhinops, which shares with the two others and lissamphibians tooth crowns with two cusps (bicuspidity). The clade formed by Doleserpeton and Amphibamus was since conceived the most plausible stem-group of Lissamphibia by many authors (Milner, 1988, 1993; Trueb and Cloutier, 1991; Ruta et al., 2003; Schoch and Milner, 2004; Ruta and Coates, 2007), except for those upholding a non-temnospondyl origin for lissamphibians (Laurin and Reisz, 1997; Laurin, 1998; Vallin and Laurin, 2004; Marjanovic and Laurin, 2008, 2009, 2013).

Jenkins and Walsh (1993) discovered skeletons of a Jurassic stem-caecilian with rudimentary limbs, which they named Eocaecilia micropodia. In the course of studying this interesting stem taxon, Jenkins et al. (2007) and Maddin et al. (2012) discovered numerous plesiomorphic characters in the skeleton of Eocaecilia, most notably the retention of dermal bones in the skull that are lost in extant lissamphibians. This demonstrated that batrachians (salamanders and frogs) and caecilians must have lost these elements convergently.

A further milestone was taken by Anderson et al. (2008a) who named and described the lower Permian amphibamid Gerobatrachus hottoni from Texas. This taxon retains a full complement of dermal bones in the skull contrasting the reduced set of dermal bones in batrachians. However, these elements cover much smaller areas than in other temnospondyls, giving expanded orbits and highly reduced strut-like palatal elements, much like in salamanders and frogs. At the same time, the cylindrical vertebrae are reduced to 17 presacrals, the lowest count among temnospondyls and just slightly higher than that of batrachians. Because of its possession of a basale commune in the tarsus, which is a feature of salamanders, Gerobatrachus has been considered a stem-batrachian (Anderson et al., 2008a) rather than ancestral to all lissamphibians, which was since found as an alternative placement (Fröbisch and Schoch, 2009a).

Recently, Pardo et al. (2017) reported a tiny stereospondyl temnospondyl, Chinlestegophis jenkinsi Pardo, Small, and Huttenlocker, 2017, which they argued shares derived features with caecilians and Eocaecilia. On this basis, they proposed a new diphyletic origin of lissamphibians, with batrachians having evolved from amphibamid dissorophoids, but caecilians from brachyopoid stereospondyls. This remains an open question that needs an inclusive analysis to be carried out in the future.

At any rate, the discovery of Eocaecilia and Gerobatrachus brought an end to the long-practiced separate treatment of temnospondyls and lissamphibians, because both Eocaecilia and Gerobatrachus retained dermal bones that are not present in any extant lissamphibian, but are well known from temnospondyls. The alternative placements of Gerobatrachus indicate that-given the temnospondyl hypothesis of lissamphibian origin is true-some amphibamids are most probably more closely related to lissamphibians (or batrachians) than others. The Amphibamidae has therefore come increasingly into the focus of studies on the origin of lissamphibians. This is irrespective of whether all extant taxa or only batrachians were derived from amphibamids, a discussion that is still in a state of flux (Anderson, 2008; Pardo et al., 2017). Amphibamid relationships within dissorophoids therefore form a central problem that also involves the nature of the Branchiosauridae and the primitive condition of Dissorophoidea as a whole.

Objectives.-This study aims to resolve or constrain the following major questions of dissorophoid phylogeny:

What does the large-scale phylogeny of Dissorophoidea look like?

What is the position of the enigmatic taxon Perryella?

Do Micromelerpetidae form a clade and where do they nest?

Do Branchiosauridae form a clade and where do they nest?

What is the relationship of Doleserpeton and Gerobatrachus to Lissamphibia/Batrachia?

What is the most likely evolutionary scenario for the origin of the Dissorophoidea and the origin and early diversification of Lissamphibia/Batrachia?

The olsoniforms, which were studied in detail elsewhere (Schoch, 2012; Maddin et al., 2013; Schoch and Sues, 2013), are not represented by a complete set of known taxa, but a smaller selection representative of their diversity.

\section{Phylogenetic analysis}

Taxon sampling.- The goal of the phylogenetic analysis was to cover as wide a range of well-studied dissorophoid taxa as possible, with the focus on the origin and diversification of this clade and the in-group relationships of amphibamids. Other questions have been addressed elsewhere, such as the placement of dissorophoids among temnospondyls (Schoch, 2013) or the 
evolutionary history of olsoniforms (Schoch, 2012; Holmes et al., 2013; Maddin et al., 2013; Schoch and Sues, 2013). Although kept relatively large, the number of taxa has been restricted to address the specific questions formulated above. To this end, datasets for amphibamids (Schoch and Rubidge, 2005; Anderson et al., 2008a, b; Fröbisch and Reisz, 2008; Sigurdsen and Bolt, 2010), dissorophids (Schoch, 2012; Holmes et al., 2013; Maddin et al., 2013), and branchiosaurids (Schoch and Milner, 2008; Fröbisch and Schoch, 2009a) have been combined, recoded in some places (indicated in Supplemental Dataset), and additional new characters were added. Throughout, the data set from which the coding was adopted is cited. In order to elucidate the origin of lissamphibians, three representative stem taxa were chosen, interpreted to reflect the primitive condition, the salientian (stem-anuran) Triadobatrachus, the urodele (stem-caudate) Karaurus, and the apodan (stem-gymnophionan) Eocaecilia, which are also fairly consistent with the primitive condition, as assessed by analysis of character distribution in the crown-groups (Schoch, 2014a). The analysis of the recently reported Chinlestegophis is spared for a separate study in the future.

The following taxa have been included in the phylogenetic analysis.

Outgroup:

Dendrysekos helogenes Steen, 1931 (Holmes et al., 1998; Schoch and Milner, 2014).

Ingroups:

1. Trimerorhachis insignis Cope, 1878 (Case, 1935; Milner and Schoch, 2013).

2. Sclerocephalus haeuseri Goldfuss, 1847 (Boy, 1988; Schoch and Witzmann, 2009).

3. Acanthostomatops vorax (Credner, 1883) (Boy, 1989; Witzmann and Schoch, 2006).

4. Perryella olsoni Carlson, 1987 (Case, 1935; Ruta and Bolt, 2006).

5. Micromelerpeton credneri (Bulman and Whittard, 1926) (Boy, 1972, 1995; Schoch and Milner, 2014).

6. Limnogyrinus elegans Fritsch, 1881 (Werneburg, 1994).

7. Branchierpeton amblystomum (Credner, 1881) (Werneburg, 1991).

8. Eimerisaurus graumanni (Boy, 1980) (Boy, 2002b).

9. Branchiosaurus salamandroides Fritsch, 1876 (Boy, 1987; Werneburg, 2012; Schoch and Milner, 2014).

10. Apateon gracilis (Boy, 1987; Werneburg, 1991; Schoch and Fröbisch, 2006).

11. Leptorophus tener Schönfeld, 1911 (Boy, 1986, 1987).

12. Schoenfelderpeton prescheri Boy, 1986 (Boy, 1987).

13. Amphibamus grandiceps (Milner, 1982; Bolt, 1969, 1979).

14. Doleserpeton annectens Bolt, 1969 (Bold, 1977; Sigurdsen and Bolt, 2010).

15. Gerobatrachus hottoni Anderson et al., 2008a.

16. Georgenthalia clavinasica Anderson et al., 2008b.

17. Eoscopus lockardi Daly, 1994.

18. Platyrhinops lyelli (Wyman, 1858) (Carroll, 1964; Clack and Milner, 2010).

19. Micropholis stowi Huxley, 1859 (Broili and Schröder, 1937; Boy, 1985; Schoch and Rubidge, 2005).
20. Tersomius texensis Case, 1910 (Carroll, 1964; Maddin et al., 2013).

21. Pasawioops mayi Fröbisch and Reisz, 2008.

22. Fedexia striegeli Berman et al., 2010.

23. Acheloma dunni Polley and Reisz, 2011.

24. Phonerpeton pricei Dilkes, 1990.

25. Ecolsonia cutlerensis Berman et al., 1985.

26. Broiliellus texensis Williston, 1914 (Carroll, 1964; Schoch, 2012).

27. Dissorophus multicinctus Cope, 1895 (Carroll, 1964; DeMar, 1968; Schoch, 2012).

28. Cacops morrisi Reisz et al., 2009.

29. Conjunctio multidens Carroll, 1964 (Schoch and Sues, 2013).

30. Triadobatrachus massinoti Piveteau, 1936 (Rage and Roček, 1989; Ascarrunz et al., 2016).

31. Karaurus sharovi Ivakhnenko, 1978.

32. Eocaecilia micropodia Jenkins and Walsh, 1993 (Jenkins et al., 2007).

Character sampling.-Many previously used characters were revised and others excluded because they were uninformative for the present range of taxa. For instance, characters 30, 46, and 47 of Schoch and Rubidge (2005), and character 51 of Anderson et al. (2008b) have been omitted because they were found not to be defined clearly enough; otherwise the characters added by Anderson et al. (2008b) are included in the present in data set, albeit with some modified coding. In addition, I have added 38 characters from other sources, including some newly formulated ones. Altogether, the dataset includes 108 discrete morphological characters sampled from all over the temnospondyl skeleton. The complete list of characters is given in the Supplemental Dataset.

Analysis.-The parsimony analysis was performed in TNT 1.5 (available at http://www.cladistics.org/tnt.html) using the New Technology Search option, which generated 10 equally most parsimonious trees (tree length $[\mathrm{TL}]=282$ steps; consistency index $[\mathrm{CI}]=0.429$; retention index $[\mathrm{RI}]=0.711$ ). Multistate characters $(1,45,53,67,75,94)$ were ordered. When these six characters were left unordered, the topology of the strict consensus tree remained the same. Dendrysekos (=Dendrerpeton of many former authors who referred to Holmes et al., 1998) has served as only outgroup taxon. The non-dissorophoid ingroup taxa are Trimerorhachis (for Dvinosauria), Sclerocephalus (for Eryopiformes), and Acanthostomatops (for Zatracheidae).

Results.-The resulting 10 trees produce seven polytomies in the strict consensus. Homoplasies are common. The Dissorophoidea (sensu Schoch and Milner, 2014), Micromelerpetidae (for spelling, see Schoch and Milner, 2014), Xerodromes, Olsoniformes, Dissorophidae, and the Amphibamiformes + Lissamphibia clade each form stable nodes (see Bremer support values given in the following tree description). The main instabilities are located: (1) within the higher Micromelerpetidae (Eimerisaurus, Branchierpeton, Limnogyrinus); (2) the Trematopidae (Ecolsonia, Fedexia, and 
advanced trematopids); (3) the base of the AmphibamidaeLissamphibia clade (Eoscopus, Platyrhinops, all higher taxa); and (4) the higher Amphibamiformes (phylogenetic definition see next scetion), which encompass an unresolved polytomy between Georgenthalia, Branchiosauridae, Gerobatrachus and Lissamphibia. The following nodes were found in the main analysis of 33 taxa and 108 characters (see also Fig. 1.1):

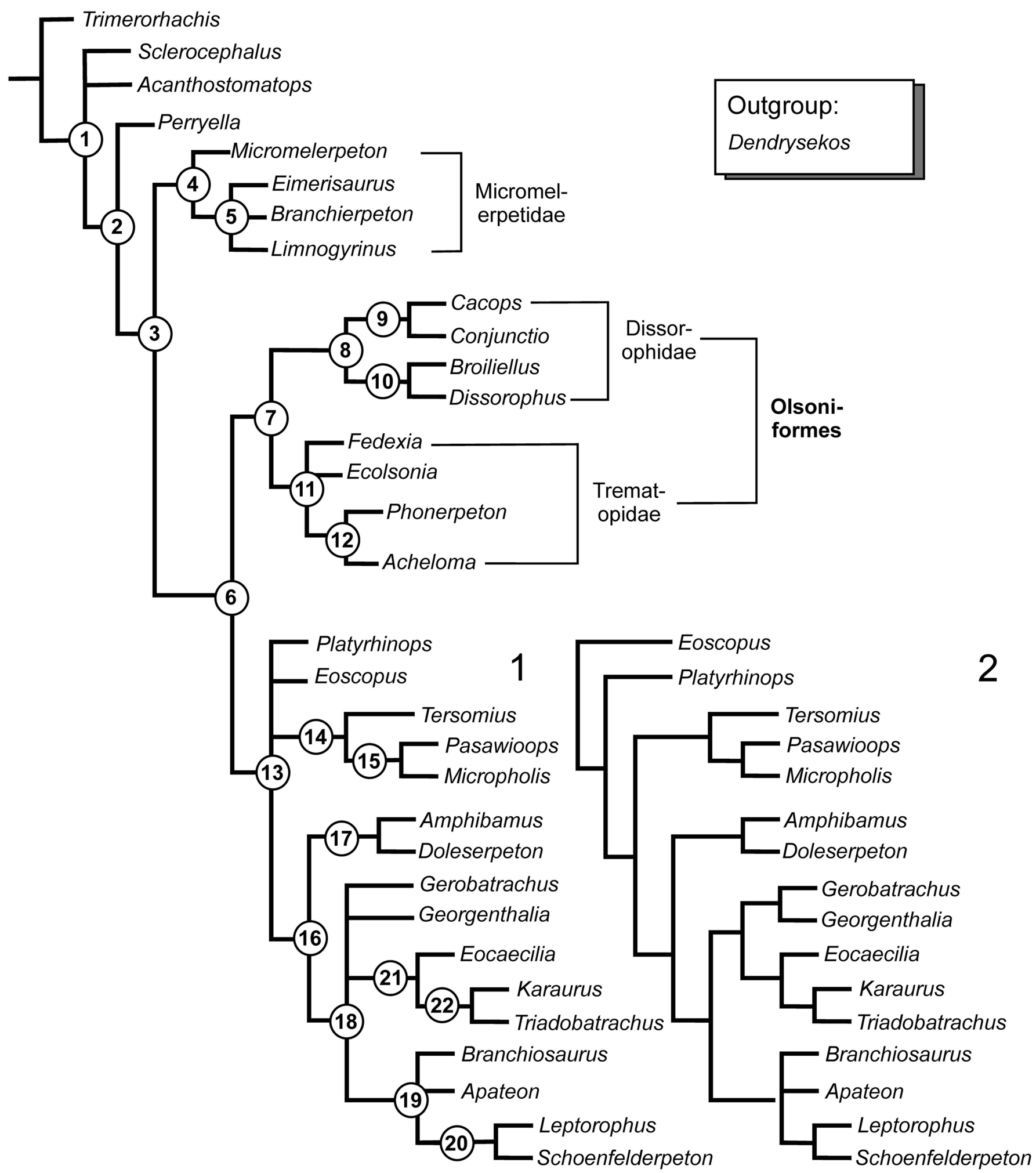

Figure 1. Phylogeny of dissorophoids as found by present analysis. Strict consensus of ten MPTs, 282 steps, CI $=0.429, \mathrm{RI}=0.711$. (1) Main data set (108 characters); (2) variant analysis, giving slightly better resolved Amphibamiformes (omitting characters 17 and 30). 
(1) Rhachitomi. Bremer Support: $>6$. Within Rhachitomi, and above Trimerorhachis, Sclerocephalus, Acanthostomatops, and all higher taxa form an unresolved polytomy.

(2) Perryella + Dissorophoidea. Bremer Support: 2. Synapomorphies: 9, 21, 38 .

(3) Dissorophoidea. Bremer Support: 3. Synapomorphies: 24, 30, 32.

(4) Micromelerpetidae. Bremer Support: 3. Synapomorphies: 40, 74, 77, 84.

(5) Eimerisaurus + Branchierpeton + Limnogyrinus. Bremer Support: 3. Synapomorphies: 5, 7, 38, 51. The relationships among the three genera remain unresolved.

(6) Xerodromes. Bremer Support: 5. Synapomorphies: 18, 53,88 .

(7) Olsoniformes. Bremer Support: > 6. Synapomorphies: 16, 19, 20, 28, 29, 35, 60, 90, 92.

(8) Dissorophidae. Bremer Support: 5. Synapomorphies: 4, $10,54,57,59$.

(9) Dissorophinae. Bremer Support: 5. Synapomorphies: 12, 22, 30, 61, 65 .

(10) Cacopinae. Bremer Support: 4. Synapomorphies: 17, 40, 49, 50, 55.

(11) Trematopidae. Bremer Support: 1. Synapomorphies: 39. This node contains an unresolved polytomy consisting of Ecolsonia + Fedexia + higher Trematopidae.

(12) Phonerpeton + Acheloma. Bremer Support: 3. Synapomorphies: 27, 40, 51.

(13) Amphibamiformes. Bremer Support: 5. Synapomorphies: 11, 12, 75, 93.

(14) Micropholidae. Bremer Support: 1. Synapomorphies: 34, 51.

(15) Pasawioops + Micropholis. Bremer Support: 1. Synapomorphies: 33.

(16) Post-micropholid Amphibamiformes. Bremer Support: > 6. Synapomorphies: 6, 40, 86, 91, 101.

(17) Amphibamidae. Bremer Support: 1. Synapomorphies: 71, 89, 102.

(18) Higher Amphibamiformes. Bremer Support: 1. Synapomorphies: 7, 30, 84, 100. This node contains an unresolved polytomy consisting of Georgenthalia + Branchiosauridae + Gerobatrachus + Lissamphibia.

(19) Branchiosauridae. Bremer Support: 3. Synapomorphies: $12,74,80$. This node contains an unresolved polytomy consisting of Branchiosaurus + Apateoninae + Leptorophinae.

(20) Leptorophinae. Bremer Support: 3. Synapomorphies: 17, 83, 95, 96.

(21) Lissamphibia. Bremer Support: > 6. Synapomorphies: 71, 94, 105, 107, 108.

(22) Batrachia. Bremer Support: >6. Synapomorphies: 4, 72, 89, 98, 104, 106.

Variant analyses.-Because two of the characters $(17,30)$ of Schoch and Rubidge's (2005) data set were criticized as mutually overlapping or non-independent (Holmes et al., 2013), they were omitted in variant analyses, giving a significantly higher resolution (Fig. 1.2). Exclusion of character 30 alone resulted in four MPTs, whereas omission of character 17 or both characters 17 and 30 likewise resulted in only two MPTs. In both variants, the higher Amphibamiformes were almost completely resolved, with Gerobatrachus + Georgenthalia forming the sister taxon to Eocaecilia + (Karaurus + Triadobatrachus), and in turn with the branchiosaurids forming the sister taxon of the latter clade; at the base of the Amphibamiformes, Eoscopus and Platyrhinops form successive sister taxa of Amphibamidae and the aforementioned clades.

Robustness of nodes. - The robustness of nodes and sources of instability were studied by the variant analysis of selected subsets of taxa. When Acanthostomatops is omitted, Dissorophoidea nests with Sclerocephalus rather than Trimerorhachis (seven trees). When Perryella is omitted in addition to Acanthostomatops, the result remains the same (seven trees).

\section{Systematic paleontology}

Temnospondyli Zittel, 1888

Rhachitomi Watson, 1919, sensu Schoch, 2013

Dissorophoidea Bolt, 1969

Diagnosis.-Laterally exposed palatine (LEP) (1); dorsal quadrate process (DQP) (2); stapes directed mostly laterally (24), postparietal four times wider than long (30), posterior projection of vomer absent (32), short preorbital region (51), jugal anteriorly blunt (97); medial quadratojugal process (99).

Occurrence.-Moscovian-Induan (Moscovian-Recent, if some or all lissamphibians are dissorophoids).

Definition (node).-The least inclusive clade containing Micromelerpeton credneri and Dissorophus multicinctus (Schoch, 2013).

Diversity.-Dissorophoidea in its present form contains 52 genera and 85 species (without Lissamphibia).

$$
\text { Micromelerpetidae Boy, } 1972
$$

Diagnosis._-Basipterygoid joint unossified (74), elevated presacral count (77), and unossified pubis (84); additional characters: lateral line sulci present even in large adults, bony ventral scales with thickened, knob-bearing posterior margin (Boy, 1972).

Occurrence.-Moscovian-Sakmarian.

Definition (node).- The least inclusive clade containing Micromelerpeton credneri and Branchierpeton amblystomum. Range: Moscovian-Artinskian.

Diversity.-Within the frame of the present analysis, Micromelerpetidae encompasses Micromelerpeton (three species), Eimerisaurus (two species), Limnogyrinus (two species), Nyranerpeton milneri Werneburg, 2012 (not included in analysis), and Branchierpeton (three species). 
Xerodromes Schoch and Milner, 2014

Diagnosis.-Squamosal-supratemporal suture shortened by extension of squamosal embayment (18), distance squamosal embayment-orbit foreshortened (53), trunk ribs throughout shorter (88).

Occurrence.-Moscovian-Induan (Moscovian-Recent, if some or all lissamphibians are dissorophoids).

Definition (stem).-The most inclusive clade containing Apateon pedestris, Amphibamus grandiceps, and Dissorophus multicinctus, but not Micromelerpeton credneri (Schoch and Milner, 2014).

Diversity.-Xerodromes in its present form contains 48 genera and 76 species (without Lissamphibia).

\section{Amphibamiformes new taxon}

Diagnosis.-Palatine and ectopterygoid reduced to narrow struts (11), interpterygoid vacuity greatly expanded laterally (12), humerus length:waist ratio 6:10 (75), basioccipital and supraoccipital absent (93).

Occurrence.-Moscovian-Induan (Moscovian-Recent, if some or all lissamphibians are dissorophoids).

Etymology.-Derived from the genus Amphibamus, which it contains.

Definition (stem).-The most inclusive clade containing Amphibamus grandiceps, but not Dissorophus multicinctus (Schoch and Milner, 2014).

Diversity.-Amphibamiformes in its present form contains 12 genera and 15 species.

Remarks.-The new name Amphibamiformes is here proposed for three reasons: (1) it encompasses a much larger group than the family-level name Amphibamidae suggests; in its extreme version, which has become more likely with the discovery of Doleserpeton and Gerobatrachus, it includes the more than 7,846 extant lissamphibian species (www.amphibiaweb.org as of April 18, 2018); (2) it contains the Branchiosauridae, which according to all cladistic analyses so far are retained as a clade; and (3) Amphibamiformes is a more apt sister taxon to Olsoniformes than Amphibamidae, considering that even in its smallest form (without Lissamphibia) it is comparably more speciose than its sister group.

\section{Micropholidae Watson, 1919}

Diagnosis. - Vomer with additional fang pair posterior to midvomerine depression (8), postparietal more than four times as wide as long (30), palatine bordering interpterygoid vacuity along its entire lateral margin (34), preorbital length foreshortened (51).
Occurrence.-Sakmarian-Induan.

Definition (node).-The least inclusive clade containing Tersomius texensis and Micropholis stowi. In the present analysis, Micropholidae includes Tersomius, Micropholis, and Pasawioops.

Remarks.-This clade, which has been found by some former authors (Schoch and Rubidge, 2005; Sigurdsen and Bolt, 2010), probably also contains Rubeostratilia and possibly Plemmyradytes. It is in many respects more plesiomorphic than the Amphibamidae and Branchiosauridae, as discussed below. Eoscopus may be a stem taxon of Micropholidae, sharing the additional vomerine fang pair with the clade.

\section{Amphibamidae Moodie, 1909}

Diagnosis.-Anterior trunk ribs not widened distally (71); choana medially expanded (89), patch of tiny denticles on vomer replacing tusk pair (102); additional character: squamosal posteriorly shortened, compensated by the quadratojugal.

\section{Occurrence.-Moscovian-Artinskian.}

Definition (node).-The least inclusive clade containing Amphibamus grandiceps and Doleserpeton annectens.

Remarks.-This definition is admittedly very restrictive, confining the family to a minimum of two taxa, but potentially including a still undescribed taxon from the Pennsylvanian Kinney Brick Quarry site in New Mexico (R. Werneburg, personal communication, 2017).

\section{Branchiosauridae Fritsch, 1879}

Diagnosis.-Palatine Y-shaped, posterior part separate from maxilla; ectopterygoid completely separate from maxilla; branchial denticles single, without bony base, often with brushlike tips.

Occurrence.-Moscovian-Artinskian.

Definition (node).- The least inclusive clade containing Branchiosaurus salamandroides and Schoenfelderpeton prescheri.

Diversity.-Branchiosauridae in its largest form contain five genera and 19 species (without Eumicrerpeton, Milnererpeton, and Tungussogyrinus).

Remarks.-The incompletely known taxa Milnererpeton huberi (Hunt, Lucas, and Berman, 1996) Tungussogyrinus bergi, and Eumicrerpeton parvum Moodie, 1909 have been omitted, but their possession of branchiosaurid characters makes them likely members of the clade rather than larvae of some other dissorophoid taxa, as has been proposed by former authors (Hunt et al., 1996; Werneburg, 2009; Milner in Schoch and Milner, 2014). 


\section{Evolution of major dissorophoid clades}

The evolution of dissorophoids and their relationship to extant amphibians have been analyzed by numerous authors in the 20th century, with the first detailed account given by Watson (1940), who elucidated the origin of anurans based on the examination of Amphibamus grandiceps. Subsequent seminal studies on dissorophoids were conducted by Carroll (1964) and Bolt $(1969,1977,1979)$, but these were mostly confined to aspects of character evolution, such as Bolt's discovery of pedicely in Doleserpeton and Amphibamus. Resting on Parsons and Williams' (1962, 1963) findings, Bolt (1969) proposed a common origin of Lissamphibia from within the dissorophoids. This was the first time that substantial data were provided to link extant amphibians with a single group of Paleozoic tetrapods, after lissamphibians had been considered polyphyletic by authors from different schools of thought (Holmgren, 1933; Romer, 1945; Schmalhausen, 1968). In his thorough reexamination of Amphibamus grandiceps, Bolt (1979) also considered developmental aspects, and developed a scenario in which $r$-selection might have driven the origin of lissamphibians.

The first inclusive phylogenetic analyses of dissorophoids, based on cladistic principles, were carried out by Jürgen Boy, initially focused on branchiosaurids and micromelerpetids (Boy, 1972), then expanded on dissorophoids as a whole (Boy, 1981). This author had studied the ontogeny of dissorophoids and other temnospondyls in unprecedented detail (Boy, 1974, 1978, 1988), and incorporated many of these data into his evolutionary scenarios. Having recognized the monophyletic status of branchiosaurids, he suggested that they either formed a neotenic clade or a group of larval forms whose terrestrial adults simply remained unknown. Boy also clearly distinguished micromelerpetids from branchiosaurids and amphibamids, although he considered the paedomorphic, aquatic micromelerpetids and branchiosaurids as close relatives. He was also the first author who recognized micromelerpetids and branchiosaurids as dissorophoids, after these groups had been neglected in other surveys (Romer, 1947; Carroll, 1964; Bolt, 1969).

More inclusive than any previous accounts were Milner's (1988, 1990, 1993) analyses and discussions, which also employed scenarios of heterochrony and paleoecology. This author was the first to widen the perspective by including all lissamphibians, finding that their closest relatives among Paleozoic tetrapods were indeed Amphibamus and Doleserpeton as forming successive sister taxa towards the crown, thus synthesizing the variant hypotheses of Watson (1940) and Bolt (1969). Milner was the first author who knew both the Central European branchiosaurids and the North American terrestrial dissorophoids by first-hand examination and in sufficient detail to find robust support for their relationship, as well as the close relationship between branchiosaurids and lissamphibians (Milner, 1993). He therefore went further in developing the first inclusive phylogeny of temnospondyls plus lissamphibians (Milner, 1990, 1993), and most of his hypotheses have been confirmed by computer-assisted cladistic analyses (Yates and Warren, 2000; Ruta and Coates, 2007; Schoch, 2013).

The first large-scale cladistic analysis of early tetrapods and lissamphibians was performed by Laurin and Reisz (1997), who presented the most radical alternative to Bolt's (1969) and Milner's (1988) Temnospondyl Hypothesis in proposing that all lissamphibians were derived from lysorophians, a small clade within lepospondyl microsaurs. Naturally, this analysis included various dissorophoids and notably Doleserpeton, but omitted branchiosaurids with reference to their then-believed completely immature status. In their Lepospondyl Hypothesis, Laurin and Reisz (1997) employed numerous lepospondyl features shared by sirenid, proteid, and amphiumid salamanders as well as caecilians. The implications of this study were analyzed by Schoch and Milner (2004) who argued that the lysorophianlissamphibian similarities constitute convergences produced by repeated events of neoteny (salamanders) and burrowing (caecilians). Although this new perspective was highly stimulating for further research, it primarily failed to explain the close resemblance particularly of anurans with temnospondyls, such as pedicely, the auditory apparatus, and various characters in the palate (Ruta and Coates, 2007; Sigurdsen and Green, 2011) despite efforts to surmount these problems (Laurin, 1998; Vallin and Laurin, 2004; Marjanovic and Laurin, 2008). At any rate, this intensified phylogenetic controversy had an enormous stimulating influence on the description and revision of dissorophoid taxa.

The last decade has brought various new and increasingly refined phylogenetic studies of dissorophoids, triggered by the examination of long-known taxa (Micropholis: Schoch and Rubidge, 2005; Cacops: Reisz et al., 2009; Perryella: Ruta and Bolt, 2006; Doleserpeton: Sigurdsen and Bolt, 2010; Mordex: Werneburg, 2012; Tersomius: Maddin et al., 2013) and the discovery of new species and genera (Eimerisaurus: Boy, 2002b; Plemmyradytes: Huttenlocker et al., 2007; Pasawioops: Fröbisch and Reisz, 2008; Rubeostratilia: Bourget and Anderson, 2011; Nyranerpeton: Werneburg, 2012; Reiszerpeton: Maddin et al., 2013; Scapanops: Schoch and Sues, 2013). These studies provide a much broader platform of taxa, characters, and hypotheses, which will form the basis of the following discussion.

The origin of the Dissorophoidea.-Dissorophoids must have evolved well before the Westphalian D (Moscovian: 307-315 Myr), because at that time the major clades were already established (Schoch and Milner, 2014). Morphologically, there is a considerable gap between dissorophoids and other temnospondyls. Departing from the primitive condition (edopoids, Dendrysekos, Balanerpeton), dissorophoids or certain taxa among Xerodromes with plesiomorphic traits (basal amphibamiforms, basal trematopids) have a short preorbital region, a longer postorbital skull table with elongate rectangular supratemporals, and enlarged orbits in adults, which give most taxa a juvenile appearance.

Most importantly, the enlargement of the orbits, which separated the jugal and lacrimal, correlates a dorsal expansion of the palatine (LEP), a structural innovation that evolved convergently but in a rather different morphological framework within the higher dvinosaurians (Shishkin, 1973). In dvinosaurians, the orbits were not enlarged, but shifted to the side, and only in later Permian-Triassic taxa an LEP was established, whereas the lower Permian forms retained a regular jugallacrimal contact. 
A second consistent character, the dorsal quadrate process, has been argued to have evolved in the enlarged tympanic notch of dissorophoids (Bolt and Lombard, 1985). In the palate, the interpterygoid vacuities expanded even more substantially than the orbits, pushing the pterygoid, palatine, and ectopterygoid to the margin (Watson, 1940; Carroll, 1964). This probably correlated with enlarged eye musculature (Witzmann and Werneburg, 2017). The pectoral girdle of dissorophoids is much lighter built and the limb bones are more slender and well ossified compared to in most other temnospondyls (Carroll, 1964; DeMar, 1968; Boy, 1972; Daly, 1994), although the distal end of the humerus has a modified condyle, which is still not widely known but may be another synapomorphy of dissorophoids and lissamphibians (Sigurdsen and Bolt, 2009).

The placement of the Dissorophoidea within the large-scale phylogeny of temnospondyls remains controversial. According to the existing hypotheses, the immediate sister taxon of dissorophoids may either be: (1) the zatracheids (Schoch, 1997, 2013; Holmes et al., 1998), (2) some or all eryopiforms (Milner, 1990; Yates and Warren, 2000), or (3) the dvinosaurians (Ruta and Bolt, 2006, albeit with Dendrysekos interpreted as basal dissorophoid). In an inclusive cladistic analysis, Schoch (2013) found: (1) Dvinosauria; and (2) Zatracheidae to form successive sister taxa of Dissorophoidea, although only the support for Zatracheidae was robust. The implications of a dvinosaurian-zatracheid-dissorophoid clade would leave a somewhat paradoxical situation: features shared by dvinosaurians and basal dissorophoids, such as the long posterior skull table and the laterally placed orbits, would have to be reversed in zatracheids, but these appear to have retained the primitive condition exemplified by eryopiforms. Additional shared derived characters, such as the LEP, are as mentioned before not strictly similar in dvinosaurians and dissorophoids, do not occur in zatracheids, and evolved only late in the dvinosaurian lineage, because basal taxa (Trimerorhachis, Neldasaurus, and Erpetosaurus) do not have these features (Milner and Schoch, 2013; Schoch, 2018), whereas they are present even in the basalmost dissorophoids. In turn, the character-states shared by zatracheids and dissorophoids do not require reversals within dissorophoids, and otherwise do not appear anywhere in temnospondyls (see next section). Therefore, I regard the relationship between dvinosaurians and dissorophoids as unsettled, whereas the likelihood for a zatracheid-dissorophoid clade as relatively high, as measured by the number of synapomorphies shared by the two.

In line with the aforementioned evidence, the present analysis finds that zatracheids form an unresolved trichotomy with dissorophoids and eryopiforms. Dvinosaurians are found outside this clade in all variant analyses. Interestingly, the omission of zatracheids (represented by Acanthostomatops) results in a closer placement of eryopiforms with dissorophoids rather than dvinosaurians. By phylogenetic definition, taxa below Micromelerpetidae fall outside Disorophoidea (Schoch and Milner, 2014), which puts Perryella on a grade outside this taxon.

Zatracheidae as plausible sister group.-The lower Permian Zatracheidae encompasses only three genera: Acanthostomatops (Saxony, Germany), Zatrachys (Texas, New Mexico,
Oklahoma, and Virginia), and Dasyceps (Texas, England, and Czech Republic). In their examination of the basal taxon Acanthostomatops, Boy (1989) and Witzmann and Schoch (2006) reported most developmental changes to be consistent with eryopiforms, whereas certain morphological features are shared with dissorophoids. These include the small squarish interclavicle, slender clavicles, the wide squamosal embayment, and the intervomerine and internarial fontanelles. The shared character-states are consistent with the observation that the ontogeny of both Acanthostomatops and many dissorophoids involved some metamorphosis, as outlined by Schoch (2009). As in most dissorophoids, zatracheids probably had fully terrestrial adults, whereas the juveniles were gill-bearing larvae similar to those of eryopiforms and the basal dissorophoid Micromelerpeton (Boy, 1988, 1989, 1990; Schoch, 2003; Witzmann and Pfretzschner, 2003; Witzmann and Schoch, 2006). In Acanthostomatops, metamorphosis was more gradual and stretched-out than in the branchiosaurid Apateon gracilis, which underwent a drastic transformation that is more similar to, but less pronounced than that of extant lissamphibians (Schoch and Fröbisch, 2006). The light-built pectoral girdle, stout humerus, and the absence of lateral line sulci indicate that adults of zatracheids were terrestrial, and the remodeling of the hyobranchium as well as shortening of the trunk and extreme broadening of the skull during metamorphosis (Witzmann and Schoch, 2006), which are unique features of the clade, are quite consistent with that. Zatracheids evidently underwent some substantial separate evolution since their ancestors diverged from those of dissorophoids in the early Pennsylvanian.

Perryella as basal taxon.-The small temnospondyl Perryella olsoni, from the lower Permian of Oklahoma, was first described by Carlson (1987) who considered it incertae sedis, and later referred it to the Dissorophoidea by Milner (1990). Ruta and Bolt (2006) revised the taxon and provided a masterly detailed description. Schoch and Milner (2014) considered Perryella an "amphibamid" (amphibamiform in the present framework), based especially on the narrow ectopterygoid and short palatine ramus of the pterygoid; these features are not well exposed, however. Perryella instead forms a plausible candidate for a basal dissorophoid, sharing several plesiomorphies with micromelerpetids. These include the elongate posterior skull table, with supratemporal and squamosal having a long suture, despite a substantial squamosal embayment. The orbits are markedly smaller than in dissorophoids, although the general appearance of the skull roof is similar to large specimens of Micromelerpeton and Eimerisaurus. As in large Micromelerpeton and Limnogyrinus, the postorbital is elongate and posteriorly pointed. The palatal bones bear numerous small teeth, and the parasphenoid is covered by a long denticle field on the parasphenoid. The basal plate is large, and the foramina for the internal carotid artery are placed lateral to the denticle field, which is close to micromelerpetids and amphibamiforms. Moreover, the wide jugal, the supinator, and the relatively large quadrangular interclavicle are plesiomorphic features consistent with the primitve condition of dissorophoids.

Characters shared by Perryella and Dissorophoidea are the anteriorly reduced palatine ramus and the lost prefrontal- 
postfrontal contact, admittedly two features known to have evolved in parallel repeatedly within xerodromes, as well. Due to its more elaborate squamosal embayment and the aforementioned characters, Perryella appears to nest outside Dissorophoidea sensu stricto, which makes it an interesting taxon to study the stepwise acquisition of dissorophoid characters. The three most important features of this clade, LEP, DQP, and medial quadratojugal process (MQP), were well established.

Micromelerpetidae.-This clade of small paedomorphic dissorophoids, known since Credner's $(1881,1886)$ reports on the Saxon lower Permian deposits, had long been lumped together with true branchiosaurids and larvae of seymourimorphs under the name "branchiosaurs" (Fig. 3). Micromelerpetids were first recognized as distinct from true branchiosaurids by Bulman and Whittard (1926), and their morphology was described in detail by Boy (1972, 1995, 2002a, b) and Werneburg (1988, 1991, 1994). They are mostly represented by larval or immature specimens, which co-occur with the smaller branchiosaurids and larvae of eryopiforms (Sclerocephalus, Onchiodon, Actinodon) in Central European lake deposits of lower Permian age (Boy and Sues, 2000). Their possession of an LEP and other dissorophoid characters was discovered rather late after larger adult specimens had been found, (Branchierpeton: Werneburg, 1991; Micromelerpeton: Boy, 1995), which clearly demonstrated their dissorophoid affinities. Unlike branchiosaurids, micromelerpetids had elongate bodies with 26-29 presacral vertebrae, elongate ribs, well-established lateral line sulci, and a larger quadrangular interclavicle. These features indicate aquatic locomotion and sensation, suggesting the clade formed an early aquatic dissorophoid offshoot. However, it remains an open question whether all taxa of this clade led an aquatic adult life, as large specimens of Micromelerpeton credneri lack lateral line sulci and have enlarged eyes, indicated by the sclerotic ring (Boy, 1995; F. Witzmann, personal communication, 2018).

Bulman and Whittard (1926) only knew small adults of Micromelerpeton from the Odernheim lake deposit in Germany, whose adult skull length was in the $20-25 \mathrm{~mm}$ range. After new excavations had been carried out in stratigraphically older formations, Boy (1995) reported much larger specimens, which had proportionately longer skulls $(45 \mathrm{~mm})$, with expanded posterior skull tables and polygonal ornamentation on the dermal bones (Schoch and Milner, 2014, fig. 27A). This morphology is consistent in many features with Perryella, which is nonetheless found to nest at the base of Dissorophoidea rather than with micromelerpetids.

Branchierpeton, which was confined to the eastern part of Germany, is known from a stratigraphic sequence of species that probably spanned the Pennsylvanian-Permian boundary (Werneburg, 1989, 1991). In that series, the most ancient species, B. saalense Werneburg, 1990, has a slightly narrower skull with a longer postorbital skull table, which resembles that of Eimerisaurus and Micromelerpeton. This pattern is consistent with the present phylogeny, which contradicts the traditional interpretation of Werneburg (1989), Milner (1993), and Boy (2002a) in which Limnogyrinus was the basal taxon and Micromelerpeton the most advanced. These early phylogenies were based on a few characters only, and in this case the prefrontal-postfrontal contact in Limnogyrinus was given much weight. Yet the frequent reversals of this character, as exemplified by Perryella, trematopids, branchiosaurids, and amphibamiforms, cast doubt on referring exclusively to this feature. Instead, Limnogyrinus and its close relative Nyranerpeton (Werneburg, 2012), are similar in most features to Branchierpeton, and the phylogenetic sequence suggested by the present analysis may be read as a trend towards stronger paedomorphosis. This trend also can be traced within single lineages, such as Branchierpeton (B. saalense-B. reinholdi Werneburg, 1988-B. amblystomum of Werneburg, 1989) and stratigraphically arranged morphotypes of Micromelerpeton credneri (Niederkirchen-Odernheim-Humberg of Boy, 1995). The ancient micromelerpetid is thus likely to have looked more like the large, long-skulled Micromelerpeton credneri from late Niederkirchen than more paedomorphic Limnogyrinus. However, character conflicts cannot be resolved because Limnogyrinus has a lower presacral vertebral count than the other taxa, which appears more plesiomorphic.

Micromelerpetids form a clade of early dissorophoids, which successfully explored larger, nutrition-rich lakes by extending the larval period or abandoning metamorphosis (neoteny). Their larvae were less evolved than those of true branchiosaurids (Witzmann and Pfretzschner, 2003), which had specialized marginal teeth, branchial dentition, and often retained an open cheek well within late larval stages (Boy, 1987; Schoch and Milner, 2008). In micromelerpetids, metamorphosis was not as drastic as in branchiosaurids and neotenic specimens are less clearly distinguished from metamorphosed ones (Schoch, 2009). As indicated by the well-known larvae of eryopiforms, micromelerpetid larvae are likely to form the primitive condition for dissorophoids, a point to which I shall return to below when discussing branchiosaurids.

Xerodromes.-Xerodromes form the higher, postmicromelerpetid dissorophoids, which share elongate limb bones, short trunk ribs, and light-built pectoral girdles with a small interclavicle (Fig. 4). Many xerodromes have a disproportionately wide skull, but not necessarily an extended interorbital distance. The postfrontal, postorbital, jugal, and squamosal are the main elements affected by this widening, contrasting markedly with the condition in micromelerpetids, which does not share these features. What is more, the orbits are proportionately larger than in micromelerpetids and the enlarged squamosal embayment wedges deeply between the squamosal and supratemporal, extending onto a large, rounded, unornamented area - this is found in taxa as different as Dissorophus, Platyrhinops, Apateon, and Doleserpeton; the trematopid squamosal embayment is to be regarded secondarily modified (Schoch, 2012).

The ancestral xerodrome morphology is not readily assessed because basal taxa are unknown and both olsoniforms and amphibamiforms fall into quite disparate groups with substantial numbers of autapomorphies (Maddin et al., 2013; Schoch and Milner, 2014). Among those representatives with the largest number of plesiomorphies are the amphibamiforms Tersomius, Eoscopus, and Platyrhinops and the olsoniforms Ecolsonia, Mordex, and Phonerpeton. These share with micromelerpetids the elongate postorbital skull table (supratemporals long rectangular, also in Broiliellus) and a posteriorly extended basal plate of the parasphenoid. The palatal elements 
were covered almost throughout with denticles, as retained in Platyrhinops, Phonerpeton, and Cacops. The pterygoid reached far anterior to contact the vomer, as exemplified by Phonerpeton, Acheloma, and Ecolsonia. Reduction of the anterior portion of the palatine ramus appears to have occurred in parallel in amphibamiforms and dissorophids, also because the resulting morphology of the palatine ramus differs: in amphibamiforms pushed laterally, often contacting only the ectopterygoid, and in dissorophids aligned anteriorly, with the palatine firmly sutured to the blunt anterior end of the pterygoid. Ancient xerodromes appear to have had well-sutured prefrontal and postfrontal, a feature retained in Platyrhinops and Amphibamus, as well as Mordex.

Adult xerodromes were apparently advanced over micromelerpetids in having a more definitive terrestrial existence; the two only known clades represent alternative evolutionary strategies to enable enhanced terrestriality: amphibamiforms became small salamander-like insectivores that eventually developed bicuspid pedicellate teeth, whereas olsoniforms evolved into larger predators with enlarged fangs and heavy dermal armor in some forms, as the only dissorophoids to reach sizes around a meter. In both clades, ossification of the braincase and axial skeleton was reinforced as compared with outgroups, with amphibamiforms evolving the cylindrical pleurocentrum, whereas olsoniforms strengthened the intercentrum instead and evolved uncinate processes on their ribs for further reinforcement (Bolt, 1969; Berman et al., 1985; Daly, 1994). The larval life of xerodromes is only known from branchiosaurids, which evolved neoteny and specialized larval characters; the question how widespread branchiosaurid larval features were in postmicromelerpetid taxa remains controversial. Milner (2007) and Werneburg (2012) reported branchiosaurid-like larvae in Mordex, but these specimens are more likely to fall within the population of Branchiosaurus salamandroides after reexamination. At any rate, the lissamphibian characters evolved mostly within amphibamiforms, with xerodromes only sharing the shortened ribs, light-built dermal pectoral girdle, and the tendency to form a wide skull with modern amphibiansfeatures that were much accentuated in later amphibamiform evolution.

Olsoniformes.-The monophyly of Trematopidae and Dissorophidae had long been questioned (Milner, 1993), but was eventually confirmed after reexamination of postcranial characters and the description of much better preserved skull material in both groups (Reisz et al., 2009; Polley and Reisz, 2011; Schoch, 2012; Maddin et al., 2013; Schoch and Sues, 2013). The present analysis confirms the placement and monophyletic status of the Olsoniformes, a clade that was named by Anderson et al. (2008b). A detailed discussion of olsoniform relationships and their monophyly was given by Schoch (2012).

Amphibamiformes.-This clade is rather uncontroversial and has so far mostly been referred to as Amphibamidae (Schoch and Rubidge, 2005; Huttenlocker et al., 2007; Fröbisch and Reisz, 2008; Bouget and Anderson, 2011; Maddin et al., 2013; Schoch and Milner, 2014). Basal amphibamiforms as found in the present study (Platyrhinops, Eoscopus) have rather long presacral vertebral columns in which the pleurocentra reach somewhat farther ventral than in Micromelerpeton, as Daly (1994) has shown. The interclavicle of these forms is quadrangular like in micromelerpetids, but much smaller compared with the skull or vertebral column. In the trunk, the ribs are shorter than in any other group (including olsoniforms), but the first five thoracic ribs are still substantially longer and more robust than the following ones. Basal amphibamiform skulls are heavily ornamented with many small polygonal ridges, and the circumorbital elements remain relatively large with wellestablished sutures. The posterior skull table houses elongate supratemporals as in outgroups, but the squamosal embayment is huge, and the distance between orbits and squamosal embayment is minimized but usually strengthened by ornament.

There are two alternative phylogenetic hypotheses found by the present analysis that produce equally plausible evolutionary scenarios: (1) Platyrhinops and Eoscopus form basal taxa that branched off before micropholids and higher amphibamiforms diverged, or (2) Platyrhinops nests at the base of Amphibamidae and Eoscopus at the base of Micropholidae. Because the palate of Platyrhinops retains many plesiomorphies (wide pterygoid, palatine and ectopterygoid, vomer completely covered by denticles, basal plate), this taxon has a rather ancestral appearance. On the other hand, the postorbital skull table is not as elongate as in Micropholidae and Eoscopus, which appear more plesiomorphic in this respect. In addition, the squamosal embayment is medially expanded much like in Amphibamidae sensu stricto, resulting in a laterally restricted supratemporal and tabular. Eoscopus, on the other hand, has a very wide skull due to enormously enlarged orbits, which resembles that of Georgenthalia, branchiosaurids, and especially Gerobatrachus; but these are probably convergences, as indicated by multiple lines of conflicting evidence. On the other hand, Eoscopus shares only plesiomorphies with micropholids, such as the morphology of the basal plate and posterior skull table, and with Platyrhinops it is consistent in the completely dentigerous vomer, a feature also retained in Doleserpeton and Amphibamus.

Branchiosauridae.-Over decades, the main "branchiosaur" question was: Why are branchiosaurids not simply the larvae of other amphibamiforms? The short answer to this question is: because adult branchiosaurids are known, and they differ from all other dissorophoids. Adult metamorphosed specimens were described by Werneburg (1991) and Schoch and Fröbisch (2006), who found that during metamorphosis the main branchiosaurid synapomorphies were conserved, and the adult morphology was unlike that of Amphibamus or Doleserpeton. Instead, branchiosaurids share derived features with Gerobatrachus, such as the morphology of the pterygoid and vomer, and the lack of tooth patches on these bones. These features were formerly referred to immaturity, but their presence in adult branchiosaurids, as well as their absence even in immature specimens of Platyrhinops (Clack and Milner, 2010) and Amphibamus (Milner, 1982) indicate that these features were independent of developmental changes.

First recognized by Fritsch (1879) as a distinct group, then described in detail by Credner $(1881,1886)$, the Branchiosauridae were eventually identified as a separate clade by Boy (1972). This was an important step beyond the confusion that 
existed since Romer $(1939,1947)$ had proposed them as larvae of eryopiform temnospondyls. Boy (1971) first suggested that branchiosaurids were not simply larvae of other clades, but that in most branchiosaurid species, adults retained a larval morphology, and concluded by analogy with extant salamanders that they were neotenic forms. Boy (1987) and Werneburg (1991) reported adult specimens in one species, Apateon gracilis, which were apparently metamorphosed adults. Whereas Boy (1987, p. 76) referred to them as "matured," Werneburg (1991) highlighted their metamorphosed (transformed) appearance. The different developmental pathways of branchiosaurid ontogenies were then studied in more detail by Schoch and Fröbisch (2006: metamorphosis) and Fröbisch and Schoch (2009b: neoteny). Finally, Sanchez et al. (2010) were able to confirm the neoteny hypothesis on the basis of skeletochronological and paleohistological data, revealing that sexual maturity was reached in animals retaining a larval morphology. The Branchiosauridae, as defined by Boy (1987) on the basis of synapomorphies, were first found by a cladistic analysis of Schoch and Milner (2008) and later, in the somewhat extended analyses of Fröbisch and Schoch (2009a), they were found as a clade, nesting within the amphibamiforms. The present analysis confirms this hypothesis, based on a much larger set of taxa and characters.

Branchiosaurids have a wide, abbreviated basal plate much like in Amphibamidae, but in contrast to these it lacks a denticle field. Consequently, the internal carotid foramina are located more medially and are more closely set, whereas they are located much farther laterally in larval Platyrhinops and Amphibamidae, where the denticle field pushes them far away from the central part of the basal plate. Furthermore, branchiosaurids all share a wide, Y-shaped palatine, which is present throughout ontogeny and not found in other dissorophoids (Boy, 1972, 1987; Werneburg, 1987, 1989, 1991, 2001; Schoch, 1992). The broad lateral wing of the palatine forms the only contact of the palatine with the maxilla, and the ectopterygoid is completely separate from the maxilla. Consequently, the interpterygoid vacuities are narrower than in other amphibamiforms, resembling those of trematopids and micromelerpetids. The palatine ramus of the pterygoid reaches much farther anteriorly than in most other amphibamiforms, which is quite possibly a derived feature that lends more strength to the otherwise strongly reduced palate. Again, this palatal architecture does not only characterize branchiosaurid larvae and neotenes, but also metamorphosed adults, as exemplified by Apateon gracilis (Schoch and Fröbisch, 2006).

Milner (1982) suggested that adult Amphibamus developed from a branchiosaurid larva, after he had described larval specimens from Mazon Creek originally reported by Moodie (1909) and Gregory (1950). Some of the early larvae he referred to Branchiosauridae proper (Branchiosaurus), others to Amphibamus. These specimens, although potentially of high significance, are challenging because of poor preservation. My own examination of this material, especially Eumicrerpeton parvum, has made me doubtful of this conclusion. The large specimen of Eumicrerpeton (USNM 4400; Schoch and Milner, 2014) clearly has a branchiosaurid palate architecture, and development into adult Amphibamus is conceivable only when some kind of resorption and reorientation of the palatine, ectopterygoid, and pterygoid had taken place. Although resorption and reorientation of palatal elements is well known in salamanders and probably forms the primitive condition of the clade (Lebedkina, 1979; Schoch, 1998), the ontogenetic changes of the palate in branchiosaurid metamorphosis were minimal, consisting of a broadening of the palatine, but no reorientation; the palatine ramus of the pterygoid was as long as in larvae, contacting most of the palatine medially.

In the present analysis, the genera Tungussogyrinus (?late Permian of Tunguska region, central Siberia) and Milnererpeton (Pennsylvanian of New Mexico) were omitted because they are not sufficiently known to be placed with reasonable confidence (Hunt et al., 1996; Shishkin, 1998; Schoch and Milner, 2008). This said, both Tungussogyrinus and Milnererpeton are now known to share the Y-shaped palatine and free ectopterygoid (Werneburg, 2009; Werneburg et al., 2013) with Branchiosauridae. Both taxa also share the single branchial denticles with Branchiosauridae, first reported by Credner (1881), restored by Stadtmüller (1936), and described in detail by Boy (1972). These form a modification of the plesiomorphic branchial dentition, which consists of small bony plates located on the branchial arches, bearing rows or patches of teeth, occurring in temnospondyl outgroups (eryopiforms, dvinosaurians), colosteid stem-tetrapods (Hook, 1983; Witzmann, 2013), and many osteichthyans. In branchiosaurids, the bony plates were lost and the single teeth were much thinner and often had brush-like tips, which has been interpreted as a filter-feeding device (Boy, 1972). This character forms a larval synapomorphy of branchiosaurids (Boy, 1987), but, unlike the palatal features, their distribution cannot be traced well within Dissorophoidea because unequivocal larval specimens are still only known from micromelerpetids and branchiosaurids (Boy, 1974; Schoch, 2009). Single branchial denticles were also mentioned by Milner (1982) to occur in larval Amphibamus. Branchiosaurids may thus have shared the branchial denticles with some or all amphibamiforms, and they are also known to occur in salamandroid caudate Beiyanerpeton from the Late Jurassic of Liaoning, China (Gao and Shubin, 2012) and in the Paleogene caudate Seminobatrachus (Skutschas and Gubin, 2012). The distribution of this character indicates that the single denticles were probably more widespread among dissorophoids, potentially occurring throughout amphibamiforms or even xerodromes.

Amphibamidae proper.-The two genera Doleserpeton and Amphibamus share a range of derived characters (Fig. 5), among which are the posteriorly foreshortened squamosal (compensated for by the quadratojugal), the loss of palatine and ectopterygoid tusks, extreme reduction in the width of the ectopterygoid, and reduction of the tabular to a tiny element without distinct horn. In all these features, amphibamids are more derived than branchiosaurids, but not necessarily more similar to lissamphibians. Conversely, the palatal denticles, which cover the complete vomer, pterygoid, palatine, and large areas of the parasphenoid, are a consistent feature of Amphibamus and Doleserpeton, and even found in juveniles much smaller in size than branchiosaurids. In these features, amphibamids are consistent with Platyrhinops, which developed a fully dentigerous palate early in ontogeny (Clack and 


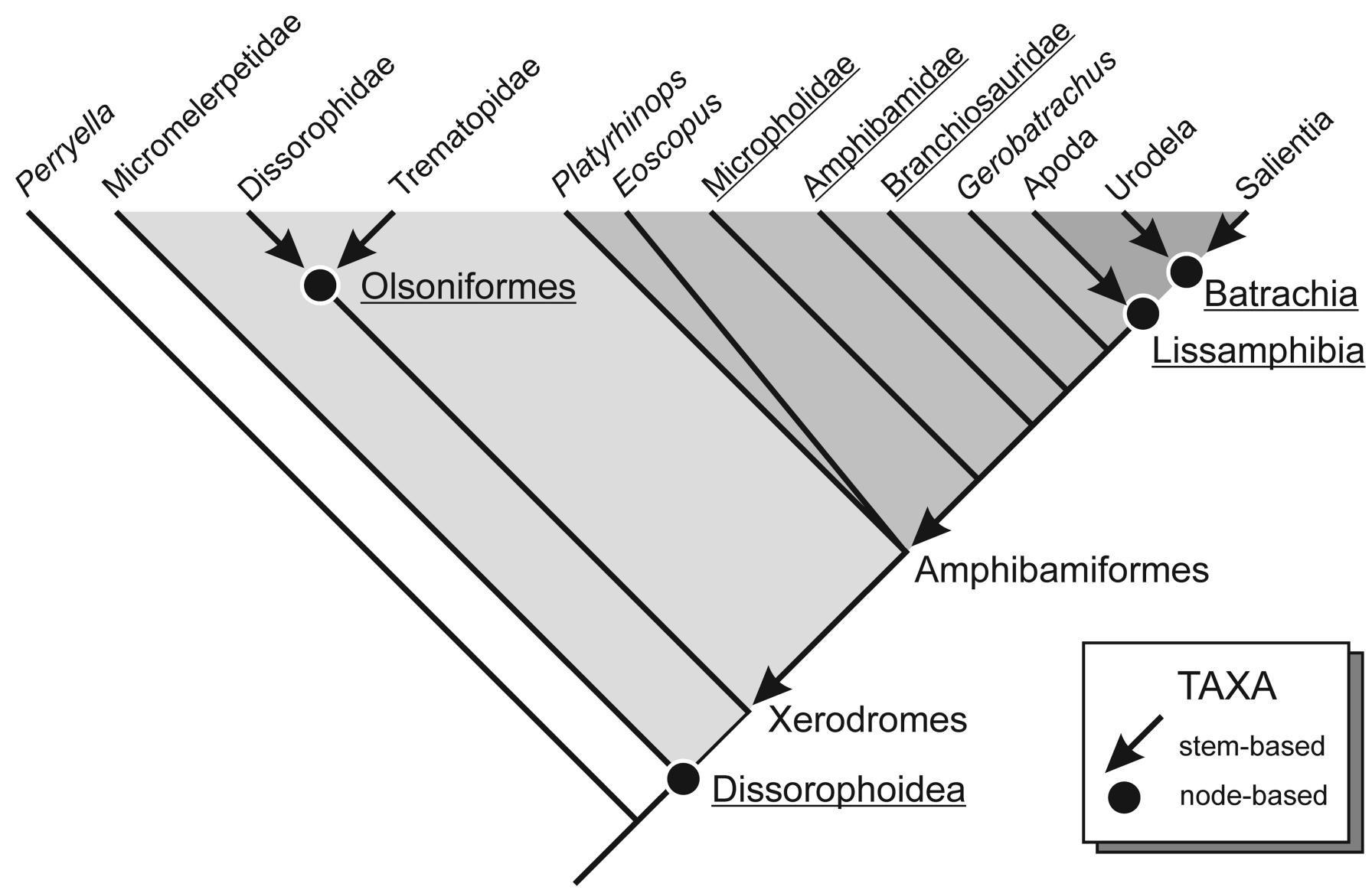

Figure 2. Phylogenetic definition of Dissorophoidea and its major constituent taxa, based on the results of the present analysis.

Milner, 2010). The small larval specimens referred to Amphibamus by Milner (1982) indeed have a triangular denticle field on the parasphenoid, which does not occur in branchiosaurids, and the tabular is tiny as in adults; the palatal elements are too poorly preserved to show whether the palatine was Y-shaped or not. Within Amphibamidae, the number of presacral vertebrae was reduced from 24 (Doleserpeton) to 18 (Amphiba$m u s)$, a trend that was paralleled within Micropholidae (Micropholis having 19) and Branchiosauridae (22-19), where the presacral count is particularly variable within species (Boy, 1972). A strict identification of small larvae on the basis of presacral numbers alone, as attempted by Werneburg (2012) to distinguish taxa, may therefore be misleading. Amphibamids were more lightly built than branchiosaurids, which is also apparent in the more delicate anterior trunk ribs in the former, as well as the less-intense ornament on the dermal skull bones. At the same time, branchiosaurids contrast amphibamids in the more-reduced areas occupied by circumorbital elements, a derived character shared with Georgenthalia and Gerobatrachus. Furthermore, amphibamids are also plesiomorphic in the retention of dentigerous palatal ossicles, which is consistent with the presence of extensive tooth patches on the vomer and palatine, whereas such ossicles are absent even in large adult branchiosaurids.

Georgenthalia and Branchiosauridae.-The incompletely known small amphibamiform Georgenthalia clavinasica shares a few characters with branchiosaurids. Although the exposed palate is more consistent with micropholids and amphibamids proper, the skull roof closely resembles that of large specimens of Branchiosaurus and Apateon, having large orbits with correlated broad postorbitals, and a much shortened posterior skull table. Also shared with branchiosaurids is the retention of substantial tabular horns. Also alternatives are equally parsimonious, Georgenthalia may form a plausible sister taxon to Branchiosauridae, in which the palatal architecture of branchiosaurids was not yet established.

Origin of lissamphibians.-The discovery of Doleserpeton, Eocaecilia, and Gerobatrachus has added substantial data to the controversy over the origin of lissamphibians, yielding some unexpected information on character evolution before and during the early diversification of lissamphibians, or at least batrachians.

Doleserpeton was essential in demonstrating that two lissamphibian characters evolved within amphibamiforms: pedicely and cylindrical pleurocentra, which gave rise to the single cylindrical centrum in Lissamphibia (Bolt, 1969). A third feature, the absence of the ectopterygoid, is now controversial: it was proposed by Bolt (1969) and retained in the new reconstruction of Sigurdsen and Bolt (2010), whereas a tiny strut-like ectopterygoid was figured in the same paper (Sigurdsen and Bolt, 2010, fig. 2). This is also a problematic character, because Gerobatrachus, which is closer to 

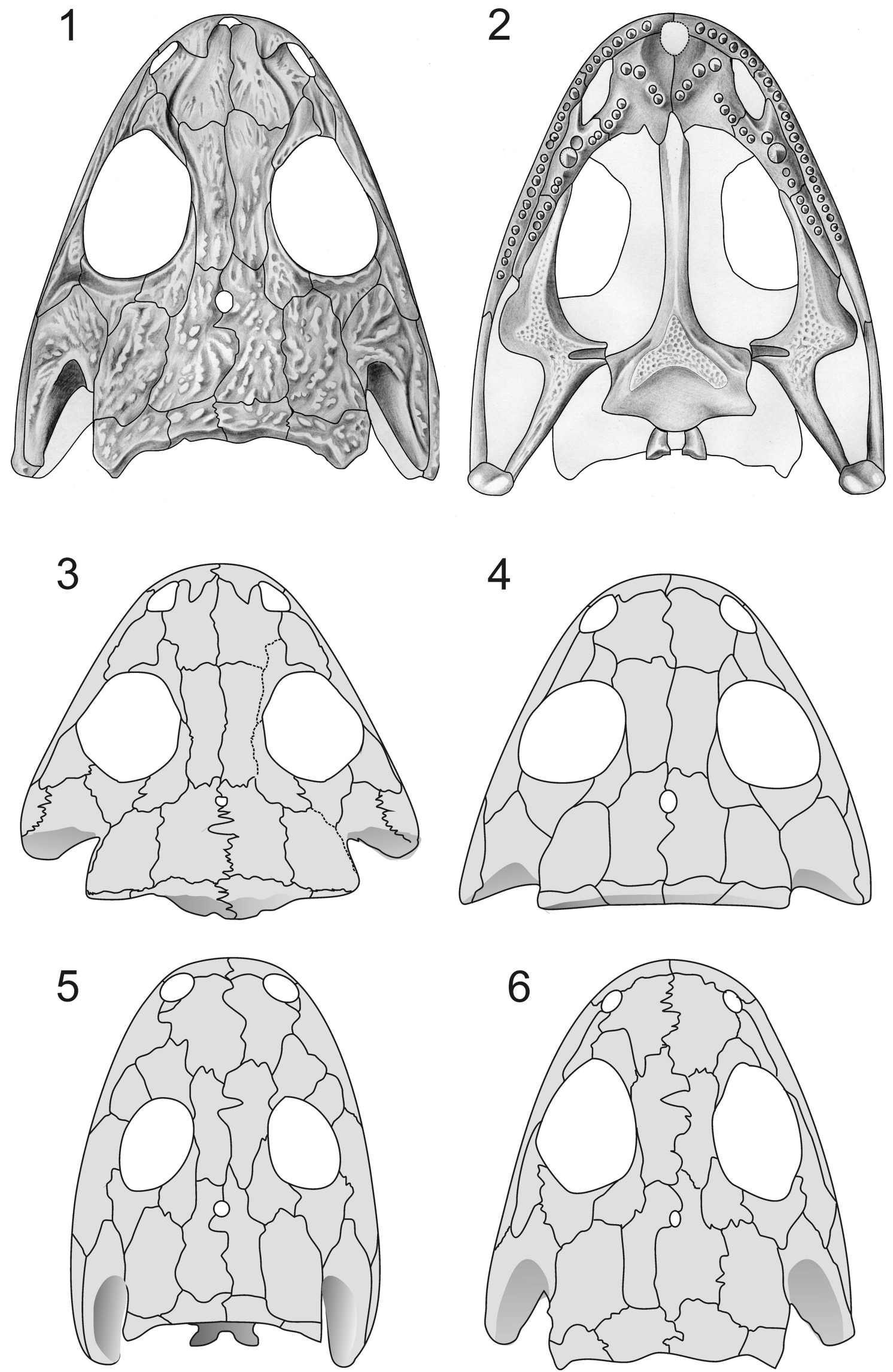

Figure 3. Morphology of basal dissorophoids (micromelerpetids) and stem taxon (Perryella). (1) Micromelerpeton credneri, skull roof (after Boy, 1995; skull length $25 \mathrm{~mm}$ ); (2) M. credneri, palate (after Boy, 1995; skull length $22 \mathrm{~mm}$ ); (3) Limnogyrinus elegans (personal observation; skull length 18 mm); (4) Branchierpeton amblystomum (after Werneburg, 1991; skull length $20 \mathrm{~mm}$ ); (5) Perryella olsoni (after Ruta and Bolt, 2006; skull length $41 \mathrm{~mm}$ ); (6)

Eimerisaurus graumanni (after Boy, 1981; skull length $32 \mathrm{~mm}$ ). 


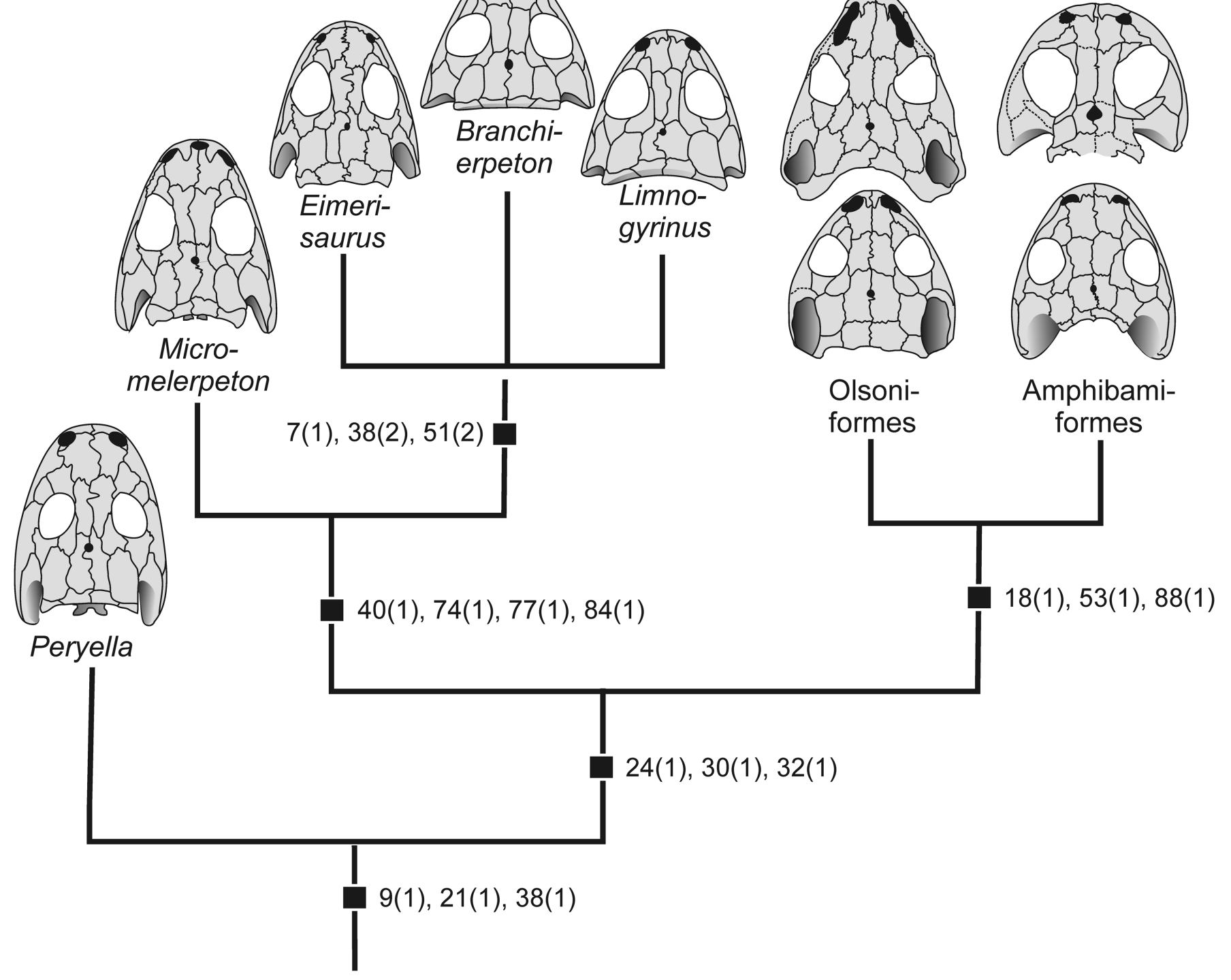

Figure 4. Phylogeny of basal dissorophoids (synapomorphies mapped, see Supplemental Dataset for character definitions).

lissamphibians in a full range of characters, retains quite a substantial ectopterygoid. The only shared character-state of amphibamids and Gerobatrachus is the absence of teeth on the ectopterygoid, a feature that also evolved in parallel within branchiosaurids, namely the leptorophine genera Melanerpeton, Leptorophus, and Schoenfelderpeton (Boy, 1987).

Pedicely and bicuspidity were later also found in Amphibamus (Bolt, 1979) and some ontogenetic stages of Tersomius (Bolt, 1977; Fig. 6). The existence of fused pedicels in the branchiosaurid Apateon pedestris remains unclear (Boy, 1978), whereas the report of pedicely in adults of the same taxon by Schoch and Carroll (2003) may be caused by breaks produced by an underlying mandible. Even in Gerobatrachus, pedicely remains controversial; the maxilla teeth of this taxon were shown to have a narrow zone that may have formed by the fusion of pedicellate crowns with their bases (Anderson et al., 2008a).

According to the evidence from Doleserpeton and Tersomius, pedicely originated in juveniles, after the peg-like larval dentition had been replaced and before fully mineralized, labyrinthodont teeth were produced (Bolt, 1977, 1979). It is conceivable that this stage was not always established, or preserved, because it may have been confined to brief developmental phases. Unlike in many other morphological features, pedicely is a condition that may be derived by incomplete mineralization of a tooth, resulting from the 

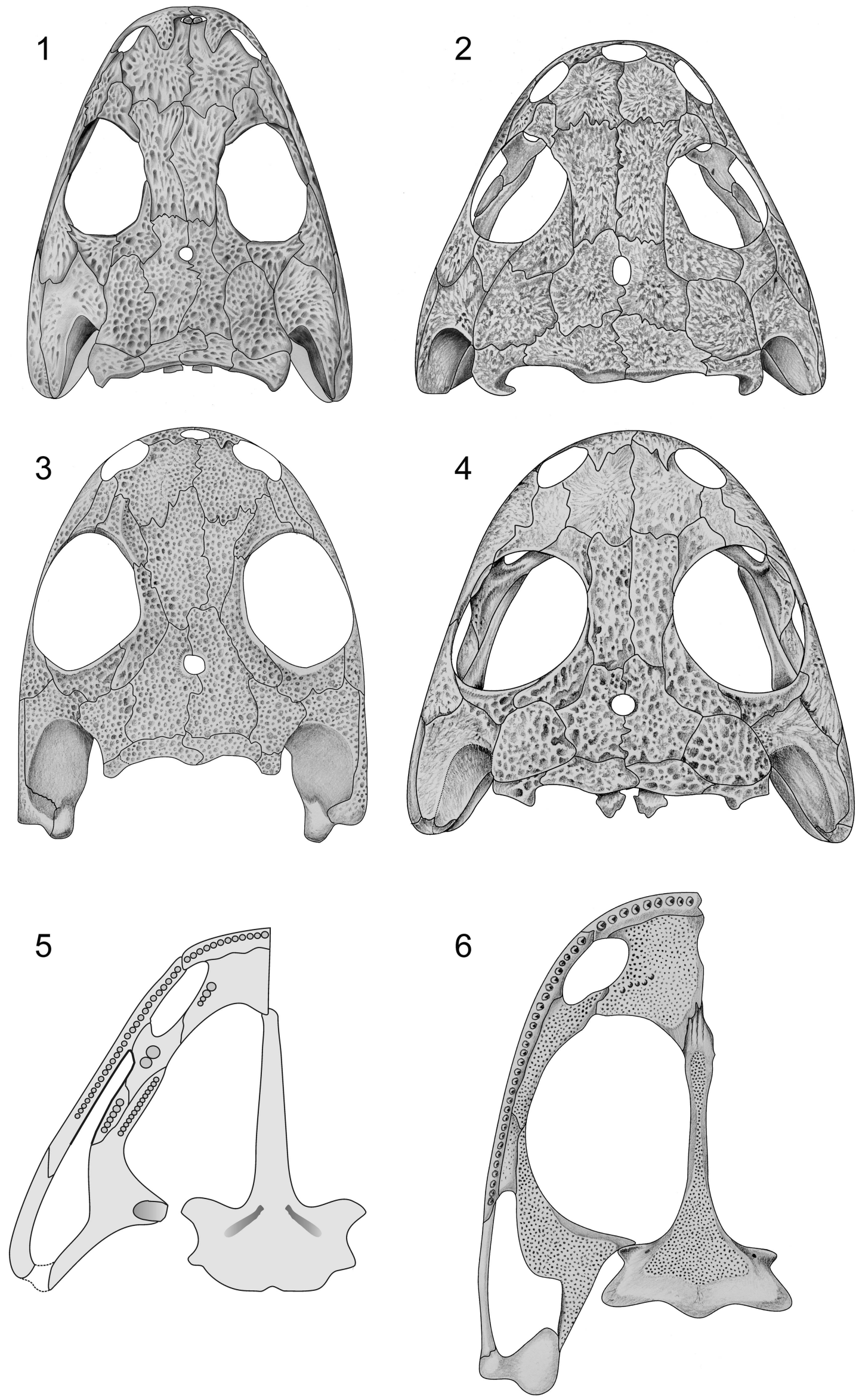

Figure 5. Morphology of amphibamiforms. (1) Micromelerpeton credneri, skull roof (Schoch and Milner, 2014; skull length $40 \mathrm{~mm}$ ); (2) Apateon caducus, skull roof of neotenic adult (Fröbisch and Schoch, 2009; skull length $29 \mathrm{~mm}$ ); (3) Amphibamus grandiceps, skull roof (personal observation; skull length $18 \mathrm{~mm}$ ); (4) Apateon gracilis, palate of metamorphosed adult (personal observation; skull length $18 \mathrm{~mm}$ ); (5) Apateon caducus, palate of neotenic adult (after Schoch, 1992; skull length $16 \mathrm{~mm}$ ); (6) Amphibamus grandiceps, palate (personal observation; skull length $18 \mathrm{~mm}$ ). 


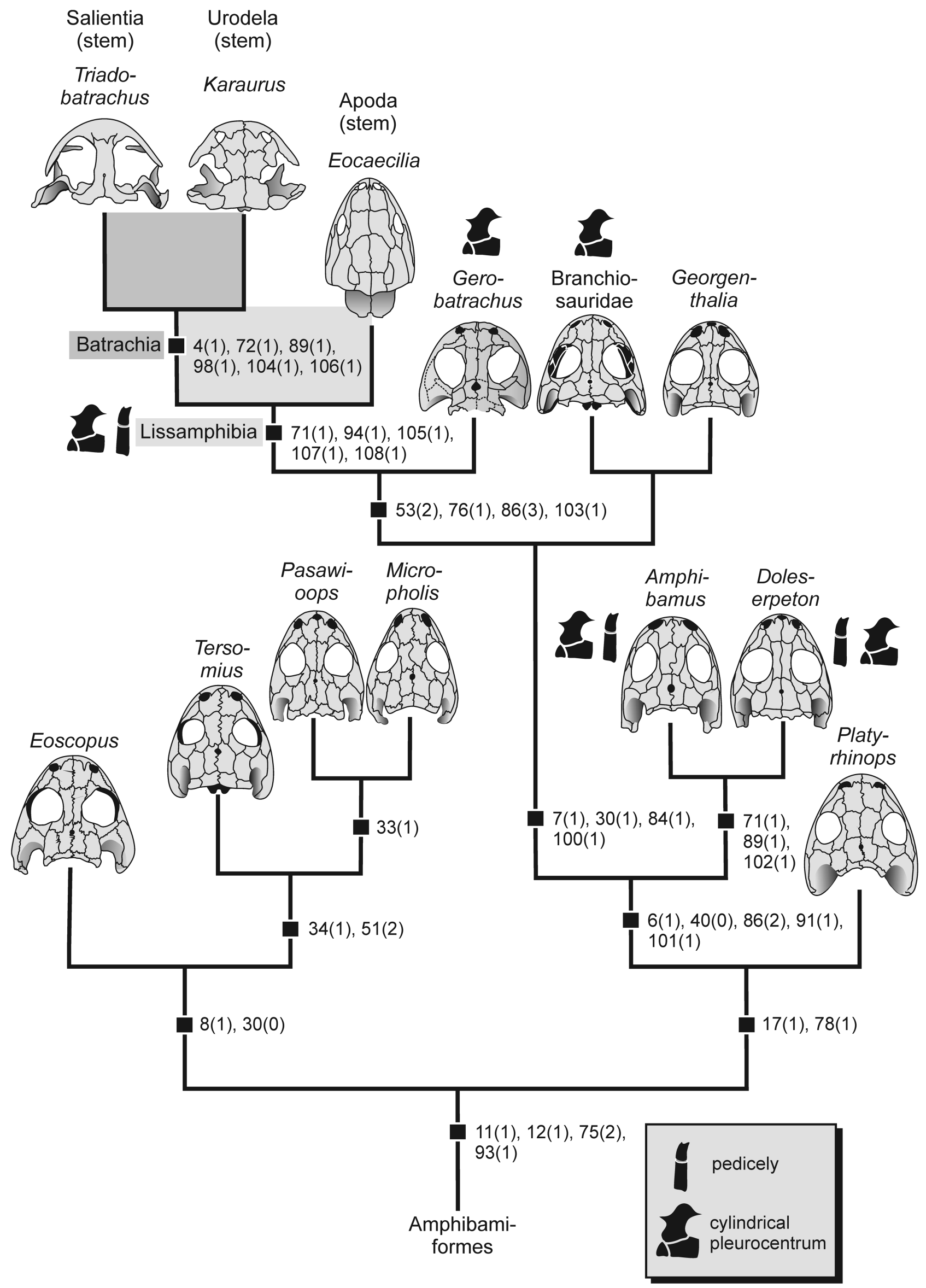

Figure 6. Phylogeny of derived dissorophoids and origin of lissamphibians according to the monophyletic temnospondyl hypothesis (synapomorphies mapped, see Supplemental Dataset for character definitions). Two lissamphibian characters (pedicely and vertebral centrum) mapped. 
existence of two separate centers of mineralization (Vasilieva and Smirnov, 2001). Thus, it may well have been absent as a discrete morphology in some stem taxa, whereas the mechanism of tooth production inherently carried pedicely as an option. Eventually it became the standard condition in lissamphibians, but even in these it was repeatedly losteither because larval teeth were retained by neoteny, or alternatively in taxa whose feeding strategy required stronger conical teeth.

In contrast to pedicely, the distribution of cylindrical pleurocentra in the current phylogenetic topology carries less conflicting evidence. Having been long known in Doleserpeton and Amphibamus, they have been found in adults of the branchiosaurid Apateon gracilis (R. Werneburg, personal communication, 2017), closely resembling those of Doleserpeton. In Gerobatrachus, as in lissamphibians, the pleurocentrum has become the dominating element.

Gerobatrachus has a parabolically wide skull, huge posteriorly extended orbits, and a disproportionately small skull table. These are batrachian features, and along with the basale commune in the tarsus (an exclusive salamander character) have been cited to support Gerobatrachus as a stem-batrachian (Anderson et al., 2008a). However, all other derived features of this taxon are consistent with the hypothesis that it forms a stemlissamphibian, which was found alternatively by Fröbisch and Schoch (2009a) and in the present analysis.

Unlike amphibamids proper, Gerobatrachus retains a remarkably branchiosaurid-like tabular horn, more massive anterior trunk ribs, and a large but autapomorphic ectopterygoid. The latter is unique among dissorophoids in expanding posteromedially to support the palatine ramus of the pterygoid, which is aligned just like in anurans, salamanders, and Eocaecilia. Like in branchiosaurids and lissamphibians, the pterygoid is entirely edentulous and its rami are reduced to thin struts, contrasting the shelved and denticle-bearing pterygoid of Doleserpeton and Amphibamus. Conversely, the palatine is much reduced and has almost lost contact to the ectopterygoid, with its vomerine process broadened much like in anurans (in adult salamanders, the palatine is absent). The rounded maxilla with its wide shelf is consistent with that of branchiosaurids as well as lissamphibians.

Considering character-states shared only by Branchiosauridae, Gerobatrachus, and Lissamphibia (see below), the Amphibamidae have lost their exclusive status as immediate lissamphibian sister taxon. This was indicated by Fröbisch and Schoch (2009a) and (implicitly) by Sigurdsen and Bolt (2010) who included Gerobatrachus in their analysis, where it nested with branchiosaurids rather than amphibamids proper. Gerobatrachus is clearly advanced over amphibamids proper and branchiosaurids in the reduced presacral count (17 instead of 18 or 19) and it has a wide parabolic skull shape consistent with that of Triadobatrachus, Karaurus, and many crown batrachians, although the primitive condition of caecilians is not yet fully known, but the skull of Eocaecilia is certainly more consistent with that of amphibamiforms in the structure of the palate than crown caecilians would suggest (e.g., the arrangement of the pterygoid, the shape of the parasphenoid, and the structure of the palatine). The teeth are much smaller, more closely set, and more numerous in Gerobatrachus and lissamphibians, as contrasted with all other amphibamiforms. Moreover, the premaxilla has a thin dorsal (alar) process, again more consistent with that of lissamphibians than with branchiosaurids or amphibamids.

\section{Acknowledgments}

I thank I. Rosin, M. Kamenz, and N. Adorf for their skillful preparation of material and casts, J. Boy, A. Milner, and R. Werneburg for many discussions, and J. Anderson, N. Fröbisch, and F. Witzmann for their constructive and helpful reviews.

\section{Accessibility of supplemental data}

Data available from the Dryad Digital Repository: https://doi.org/10.5061/dryad.1n1p0b5.2

\section{References}

Anderson, J.S., 2008, Focal review: the origin(s) of modern amphibians: Evolutionary Biology, v. 35, p. 231-247.

Anderson, J.S., Reisz, R.R., Scott, D., Fröbisch, N.B., and Sumida, S.S., 2008a, A stem batrachian from the Early Permian of Texas and the origin of frogs and salamanders: Nature, v. 453, p. 515-518.

Anderson, J.S., Henrici, A.C., Sumida, S.S., Martens, T., and Berman, D.S., 2008b, Georgenthalia clavinasica, a new genus and species of dissorophoid temnospondyl from the Early Permian of Germany, and the relationships of the Family Amphibamidae: Journal of Vertebrate Paleontology, v. 28, p. 61-75.

Ascarrunz, E., Rage, J.C., Legreneur, P., and Laurin, M., 2016, Triadobatrachus massinoti, the earliest known lissamphibian (Vertebrata: Tetrapoda) reexamined by $\mu \mathrm{CT}$ scan, and the evolution of trunk length in batrachians: Contributions to Zoology, v. 85, p. 201-234.

Berman, D.S., Reisz, R.R., and Eberth, D.A., 1985, Ecolsonia cutlerensis, an early Permian dissorophid amphibian from the Cutler Formation of northcentral New Mexico: New Mexico Bureau of Mines and Mineral Resources Circular, v. 191, p. 1-31.

Berman, D.S., Henrici, A.C., Brezinski, D.K., and Kollar, A.D., 2010, A new trematopid amphibian (Temnospondyli: Dissorophoidea) from the Upper Pennsylvanian of western Pennsylvania: earliest record of terrestrial vertebrates responding to a warmer, drier climate: Annals of the Carnegie Museum, v. 78, p. 289-318.

Bolt, J.R., 1969, Lissamphibian origins: possible protolissamphibian from the Lower Permian of Oklahoma: Science, v. 166, p. 888-891.

Bolt, J.R., 1977, Dissorophoid relationships and ontogeny, and the origin of the Lissamphibia: Journal of Paleontology, v. 51, p. 235-249.

Bolt, J.R., 1979, Amphibamus grandiceps as a juvenile dissorophid: evidence and implications, in Nitecki, M., ed., Mazon CreekFossils: New York, Academic Press, p. 529-563.

Bolt, J.R., and Lombard, R.E., 1985, Evolution of the amphibian tympanic ear and the origin of frogs: Biological Journal of he Linnean Society, v. 24, p. 83-99.

Bourget, H., and Anderson, J.S., 2011, A new amphibamid (Temnospondyli: Dissorophoidea) from the Early Permian of Texas: Journal of Vertebrate Paleontology, v. 31, p. 32-49.

Boy, J.A., 1971, Zur Problematik der Branchiosaurier (Amphibia; KarbonPerm): Paläontologische Zeitschrift, v. 45, p. 107-119.

Boy, J.A., 1972, Die Branchiosaurier (Amphibia) des saarpfälzischen Rotliegenden (Perm, SW-Deutschland): Hessisches Landesamt für Bodenforschung, v. 65, p. 1-137.

Boy, J.A., 1974, Die Larven der rhachitomen Amphibien (Amphibia: Temnospondyli; Karbon-Trias): Paläontologische Zeitschrift, v. 48, p. 236-268.

Boy, J.A., 1978, Die Tetrapodenfauna (Amphibia, Reptilia) des saarpfälzischen Rotliegenden (Unter-Perm; SW-Deutschland). 1. Branchiosaurus: Mainzer geowissenschaftliche Mitteilungen, v. 7, p. 27-76

Boy, J.A., 1980, Die Tetrapodenfauna (Amphibia, Reptilia) des saarpfälzischen Rotliegenden (Unter-Perm; SW-Deutschland). 2. Tersomius graumanni $\mathrm{n}$. sp.: Mainzer geowissenschaftliche Mitteilungen, v. 8, p. 17-30.

Boy, J.A., 1981, Zur Anwendung der Hennigschen Methode in der Wirbeltierpaläontologie: Paläontologische Zeitschrift, v. 55, p. 87-107.

Boy, J.A., 1985, Über Micropholis, den letzten Überlebenden der Dissorophoidea (Amphibia, Temnospondyli; Unter-Trias): Neues Jahrbuch für Geologie und Paläontologie, Monatshefte, v. 1985, p. 29-45. 
Boy, J.A., 1986, Studien über die Branchiosauridae (Amphibia: Temnospondyli). 1. Neue und wenig bekannte Arten aus dem mitteleuropäischen Rotliegenden (?oberes Karbon bis unteres Perm): Paläontologische Zeitschrift, v. 60, p. 131-166.

Boy, J.A., 1987, Studien über die Branchiosauridae (Amphibia: Temnospondyli, Ober-Karbon-Unter-Perm). 2. Systematische Übersicht: Neues Jahrbuch für Geologie und Paläontologie, Abhandlungen, v. 174, p. 75-104.

Boy, J.A., 1988, Über einige Vertreter der Eryopoidea (Amphibia: Temnospondyli). 1. Sclerocephalus: Paläontologische Zeitschrift, v. 62, p. 429457.

Boy, J.A., 1989, Über einige Vertreter der Eryopoidea (Amphibia: Temnospondyli). 2. Acanthostomatops: Paläontologische Zeitschrift, v. 63, p. 133151.

Boy, J.A., 1990, Über einige Vertreter der Eryopoidea (Amphibia: Temnospondyli). 3. Onchiodon: Paläontologische Zeitschrift, v. 64, p. 287-312.

Boy, J.A., 1995, Über die Micromelerpetontidae (Amphibia: Temnospondyli). 1. Morphologie und Paläoökologie des Micromelerpeton credneri (UnterPerm; SW-Deutschland): Paläontologische Zeitschrift, v. 69, p. 429-457.

Boy, J.A., 2002a, Über die Micromelerpetontidae (Amphibia: Temnospondyli). 2. Micromelerpeton ulmetense $\mathrm{n}$. sp. und ?Micromelerpeton boyi Heyler Neues Jahrbuch für Geologie und Paläontologie, Abhandlungen, v. 223, p. $241-274$.

Boy, J.A., 2002b, Über die Micromelerpetontidae (Amphibia: Temnospondyli). 3. Eimerisaurus n. g.: Neues Jahrbuch für Geologie und Paläontologie, Abhandlungen, v. 225, p. 425-452.

Boy, J.A., and Sues, H.-D., 2000, Branchiosaurs: larvae, metamorphosis and heterochrony in temnospondyls and seymouriamorphs, in Heatwole, $\mathrm{H}$. and Carroll, R.L. (eds) Amphibian Biology, Vol 4, Palaeontology, Chipping Norton, NSW, Australia: Surrey Beatty and Sons, p. 1150-1197.

Broili, F., and Schröder, J., 1937, Beobachtungen an Wirbeltieren der Karrooformation. XXV. Über Micropholis Huxley. XXVI. Über Lydekkerina Broom: Sitzungsberichte der Bayerischen Akademie der Wissenschaften, Mathematisch-Naturwissenschaftliche Abteilung, v. 1937, p. $19-57$.

Bulman, O.M.B., and Whittard, W.F., 1926, On Branchiosaurus and allied genera: Proceedings of the Zoological Society London, v. 1926, p. 533-579.

Carlson, K.J., 1987, Perryella, a new temnospondylous amphibian from the Lower Permian of Oklahoma: Journal of Paleontology, v. 61, p. 135-147.

Carroll, R.L., 1964, Early evolution of the dissorophoid amphibians: Bulletin of the Museum of Comparative Zoology, Harvard University, v. 131, p. 161250.

Carroll, R.L., and Currie, P., 1975, Microsaurs as possible apodan ancestors: Zoological Journal of the Linnean Society, v. 57, p. 229-247.

Carroll, R.L., and Holmes, R., 1980, The skull and jaw musculature as a guide to the ancestry of salamanders: Zoological Journal of the Linnean Society, v. 68 , p. $1-40$.

Case, E.C., 1910, New and little known reptiles from the Permian of Texas: Bulletin of the American Museum of Natural History, v. 28, p. 163-181

Case, E.C., 1935, Description of a collection of associated skeletons of Trimerorhachis: Contributions of the Museum of Paleontology, University of Michigan, v. 4, p. 227-274.

Clack, J.A., and Milner, A.R., 2010, Morphology and systematics of the Pennsylvanian amphibian Platyrhinops lyelli (Amphibia: Temnospondyli): Earth and Environmental Science Transactions of the Royal Society of Edinburgh, v. 100, p. 275-295.

Cope, E.D., 1865, On Amphibamus grandiceps, a new batrachian from the coalmeasures: Proceedings of the Academy of Natural Sciences Philadelphia, v 1865 , p. $134-137$.

Cope, E.D., 1878, Description of extinct Batrachia and Reptilia from the Permian Formation of Texas: Proceedings of the American Philosophical Society, v. 17 , p. $505-530$

Cope, E.D., 1895, A batrachian armadillo: American Naturalist, v. 29, p. 998.

Credner, H., 1881, Die Stegocephalen aus dem Rothliegenden des Plauen'schen Grundes bei Dresden. Erster Theil: Zeitschrift der deutschen geologischen Gesellschaft, v. 33, p. 298-330.

Credner, H., 1883, Die Stegocephalen aus dem Rothliegenden des Plauen'schen Grundes bei Dresden. Vierter Theil: Zeitschrift der deutschen geologischen Gesellschaft, v. 35, p. 275-300.

Credner, H., 1886, Die Stegocephalen aus dem Rothliegenden des Plauen'schen Grundes bei Dresden. Sechster Theil: Zeitschrift der deutschen geologischen Gesellschaft, v. 38, p. 576-633.

Daly, E., 1994, The Amphibamidae (Amphibia: Temnospondyli), with a description of a new genus from the Upper Pennsylvanian of Kansas: The University of Kansas, Miscellaneous Publications, v. 85, p. 1-59.

Danto, M., Witzmann, F., and Fröbisch, N.B., 2016, Vertebral Development in Paleozoic and Mesozoic Tetrapods Revealed by Paleohistological Data: PLoS ONE, v. 11(4), e0152586.
DeMar, R.E., 1968, The Permian labyrinthodont amphibian Dissorophus multicinctus and adaptations and phylogeny of the family Dissorophidae: Journal of Paleontology, v. 42, p. 1210-1242.

Dilkes, D., 1990, A new trematopsid amphibian (Temnospondyli: Dissorophoidea) from the Lower Permian of Texas: Journal of Vertebrate Paleontology, v. 10, p. 222-243.

Fritsch, A., 1876, Über die Fauna der Gaskohle des Pilsner und Rakonitzer Beckens: Sitzungsberichte der königlich-böhmischen Akademie der Wissenschaften Prag, v. 1875, p. 70-79.

Fritsch, A., 1879, Fauna der Gaskohle und der Kalksteine der Permformation Böhmens: Prague, Selbstverlag, v. 1, p. 1-126.

Fritsch, A., 1881, Fauna der Gaskohle und der Kalksteine der Permformation Böhmens: Prague, Selbstverlag, v. 1, p. 127-158.

Fröbisch, N.B., and Reisz, R.R., 2008, A new Lower Permian amphibamid (Dissorophoidea, Temnospondyli) from the fissure fill deposits near Richards Spur, Oklahoma: Journal of Vertebrate Paleontology, v. 28, p. 1015-1030.

Fröbisch, N.B., and Schoch, R.R., 2009a, Testing the impact of miniaturization on phylogeny: Paleozoic dissorophoid amphibians: Systematic Biology, v. 58, p. 312-327.

Fröbisch, N.B., and Schoch, R.R., 2009b, The largest specimen of Apateon and life history pathway of neoteny in the Paleozoic temnospondyl family Branchiosauridae: Fossil Record, v. 12, p. 83-90.

Gao, K.Q., and Shubin, N.H., 2012, Late Jurassic salamandroid from Western Liaoning, China: Proceedings of the National Academy of Sciences, v. 109, p. $5767-5772$.

Gardiner, B.G., 1983, Gnathostome vertebrae and the classification of the Amphibia: Zoological Journal of the Linnean Society, v. 79, p. 1-59.

Goldfuss, A., 1847, Beiträge zur vorweltlichen Fauna des Steinkohlengebirges: Bonn, Naturhistorischer Verein der Preussischen Rheinlande, 27 p.

Gregory, J.T., 1950, Tetrapods from the Pennsylvanian nodules of Mazon Creek, Illinois: American Journal of Science, v. 248, p. 833-873.

Holmes, R.B., Carroll, R.L., and Reisz, R.R., 1998, The first articulated skeleton of Dendrerpeton acadianum (Temnospondyli, Dendrerpetontidae) from the Lower Pennsylvanian locality of Joggins, Nova Scotia, and a review of its relationships: Journal of Vertebrate Paleontology, v. 18, p. 64-79.

Holmes, R., Berman, D.S., Anderson, J.S., 2013, A new dissorophid (Temnospondyli, Dissorophoidea) from the Early Permian of New Mexico (United States): Comptes Rendus Palevol, v. 12, p. 419-435.

Holmgren, N., 1933, On the origin of the tetrapod limb: Acta Zoologica, v. 14. p. $187-248$.

Hook, R.W., 1983, Colosteus scutellatus (Newberry), a primitive temnospondyl amphibian from the Middle Pennsylvanian of Linton: American Museum of Natural History Novitates, v. 2770, p. 1-41.

Hunt, A.P., Lucas, S.G., and Berman, D.S., 1996, A new amphibamid (Amphibia: Temnospondyli) from the Late Pennsylvanian (Middle Stephanian) of central New Mexico, USA: Paläontologische Zeitschrift, v. 70, p. 555-565.

Huttenlocker, A.K., Pardo, J.D., and Small, B.J., 2007, Plemmyradytes shintoni, gen. et sp. nov., an Early Permian amphibamid (Temnospondyli: Dissorophoidea) from the Eskridge Formation, Nebraska: Journal of Vertebrate Paleontology, v. 27, p. 316-328.

Huxley, T.H., 1859, On some amphibian and reptilian remains from South Africa and Australia: Quarterly Journal of the Geological Society of London, v. 15 , p. $52-56$.

Ivakhnenko, M., 1978, Urodeles from the Triassic and Jurassic of Soviet Central Asia: Paleontological Journal, v. 12, p. 362-368.

Jenkins, F.A., and Walsh, D.M., 1993, An early Jurassic caecilian with limbs: Nature, v. 365 , p. $246-250$.

Jenkins, F.A., Walsh, D.M., and Carroll, R.L., 2007, Anatomy of Eocaecilia micropodia, a limbed caecilian of the Early Jurassic: Bulletin of the Museum of Comparative Zoology, v. 158, p. 285-365.

Laurin, M., 1998, The importance of global parsimony and historical bias in understanding tetrapod evolution. Part I. Systematics, middle ear evolution, and jaw suspension: Annales des Sciences Naturelles, Zoologie, v. 19, p. 1-42.

Laurin, M., and Reisz, R.R., 1997, A new perspective on tetrapod phylogeny, in Sumida S.S., and Martin, K.L., eds., Amniote Origins: New York, Academic Press, p. 9-59.

Lebedkina, N.S., 1979, The evolution of the amphibian skull: Nauka, Moscow, 283 p. [in Russian]

Maddin, H.C., Jenkins, F.A., and Anderson, J.S., 2012, The braincase of Eocaecilia micropodia (Lissamphibia, Gymnophiona) and the origin of caecilians: PLoS ONE, v. 7, e50743.

Maddin, H.C., Fröbisch, N.B., Evans, D.C., and Milner, A.R., 2013, Reappraisal of the early Permian amphibamid Tersomius texensis and some referred material: Comptes Rendus Palevol, v. 12, p. 447-461.

Marjanovic, D., and Laurin, M., 2008, A reevaluation of the evidence supporting an unorthodox hypothesis on the origin of extant amphibians: Contributions to Zoology, v. 77, p. 149-199. 
Marjanovic, D., and Laurin, M., 2009, The origin(s) of modern amphibians: a commentary: Evolutionary Biology, v. 36, p. 336-338.

Marjanovic, D., and Laurin, M., 2013, The origin(s) of extant amphibians: a review with emphasis on the "lepospondyl hypothesis": Geodiversitas, v. 35 , p. $207-272$

Meyer, H.v., 1848, Apateon pedestris aus der Steinkohlenformation von Münsterappel: Palaeontographica, v. 1, p. 153-154.

Milner, A.R., 1982, Small temnospondyl amphibians from the Middle Pennsylvanian of Illinois: Palaeontology, v. 25, p. 635-664.

Milner, A.R., 1988, The relationships and origin of living amphibians, in Benton, M.J., ed., The Phylogeny and Classification of the Tetrapods: Amphibians, Reptiles, Birds: Oxford, Clarendon Press, v. 1, p. 59-102.

Milner, A.R., 1990, The radiations of temnospondyl amphibians, in Taylor, P. D., and Larwood, G.P., eds., Major Evolutionary Radiations: Oxford, Clarendon Press, p. 321-349.

Milner, A.R., 1993, The Paleozoic relatives of amphibians: Herpetological Monographs, v. 7, p. 8-27.

Milner, A.R., 2007, Mordex laticeps and the base of the Trematopidae: Journal of Vertebrate Paleontology Supplement, v. 27, p. 118A.

Milner, A.R., and Schoch, R.R., 2013, Trimerorhachis (Amphibia: Temnospondyli) from the Lower Permian of Texas and New Mexico: cranial osteology, taxonomy, and biostratigraphy: Neues Jahrbuch für Geologie und Paläontologie Abhandlungen, v. 270, p. 91-128.

Moodie, R.L., 1909, A contribution to a monograph of the extinct Amphibia of North America. New forms from the Carboniferous: Journal of Geology, v. 17, p. $38-82$.

Moodie, R.L., 1916, The Coal Measures Amphibia of North America: Publications of the Carnegie Institute, Washington, v. 228, p. 1-222.

Pardo, J.D., Small, B.J., and Huttenlocker, A.K., 2017, Stem caecilian from the Triassic of Colorado sheds light on the origins of Lissamphibia: Proceedings of the National Academy of Sciences, v. 114, p. E5389-E5395.

Parsons, T.S., and Williams, E.E., 1962, The teeth of Amphibia and their relation to amphibian phylogeny: Journal of Morphology, v. 110, p. 375-389.

Parsons, T.S., and Williams, E.E., 1963, The relationships of the modern Amphibia: a re-examination: Quarterly Review of Biology, v. 38, p. 26-53.

Pérez Ben, C., Schoch, R.R., and Báez, A.M., 2018, Miniaturization and morphological evolution in Paleozoic relatives of living amphibians: a quantitative approach: Paleobiology, v. 44, p. 58-75.

Piveteau, J., 1936, Une forme ancestrale des Amphibiens Anoures dans le Trias inférieur: Annales de Paleontologie, v. 26, p. 135-177.

Polley, B. and Reisz, R.R., 2011, A new Lower Permian trematopid (Temnospondyli: Dissorophoidea) from Richards Spur, Oklahoma: Zoological Journal of the Linnean Society, v. 161, p. 789-815.

Quenstedt, F.A., 1850, Die Mastodonsaurier aus dem grünen Keupersandsteine Württemberg's sind Batrachier: Laupp and Siebeck, Tübingen, 34 p.

Rage, J.C., and Roček, Z., 1989, Redescription of Triadobatrachus massinoti (Piveteau, J., 1936), an anuran amphibian from the early Triassic: Palaeontographica, v. A206, p. 1-16.

Reig, O., 1964, El problema del origen monofilético o polifilético do los anfibios, con consideraciones sobre las relaciones entre Anuros, Urodelos y Apodos: Ameghiniana, v. 3, p. 191-211.

Reisz, R.R., Schoch, R.R., and Anderson, J.S., 2009, The armoured dissorophid Cacops from the Early Permian of Oklahoma and the exploitation of the terrestrial realm by amphibians: Naturwissenschaften, v. 96, p. 789-796.

Romer, A.S., 1930, The Pennsylvanian tetrapods from Linton, Ohio: Bulletin of the American Museum of Natural History, v. 59, p. 77-147.

Romer, A.S., 1939, Notes on branchiosaurs: American Journal of Science, v. 237, p. $748-761$.

Romer, A.S., 1945, Vertebrate Paleontology, 2nd ed.: Chicago, University of Chicago Press, 687 p.

Romer, A.S., 1947, Review of the Labyrinthodontia: Bulletin of the Museum of Comparative Zoology, Harvard University, v. 99, p. 1-368

Ruta, M., and Bolt, J.R., 2006, A reassessment of the temnospondyl amphibian Perryella olsoni from the Lower Permian of Oklahoma: Transactions of the Royal Society of Edinburgh: Earth Sciences, v. 97, p. 113-65.

Ruta, M., and Coates, M.I., 2007, Dates, nodes, and character conflict: addressing the lissamphian origin problem: Journal of Systematic Palaeontology, v. 5 , p. $69-122$.

Ruta, M., Coates, M.I., and Quicke, D.L.J., 2003, Early tetrapod relationships revisited: Biological Reviews, v. 78, p. 251-345.

Sanchez, S., De Ricqles, A., Schoch, R.R., and, Steyer, J.S., 2010, Developmental plasticity of limb bone microstructural organization in Apateon: histological evidence of paedomorphic conditions in brachiosaurs: Evolution and Development, v. 12 , p. 315-328.

Schmalhausen, I.I., 1968, The Origin of Terrestrial Vertebrates: London, Academic Press, $314 \mathrm{p}$

Schoch, R.R., 1992, Comparative ontogeny of early Permian branchiosaurid amphibians from southwestern Germany. Developmental stages: Palaeontographica, v. A 222 , p. $43-83$.
Schoch, R.R., 1997, Cranial anatomy of the temnospondyl Zatrachys serratus Cope, 1878, and the phylogenetic position of the Zatrachydidae: Neues Jahrbuch für Geologie und Paläontologie, Abhandlungen, v. 206, p. 223-48.

Schoch, R.R., 1998, Homology of cranial ossifications in urodeles: significance of developmental data for fossil basal tetrapods: Neues Jahrbuch für Geologie und Paläontologie Abhandlungen, v. 1998, p. 1-25.

Schoch, R.R., 2003, The early larval ontogeny of the Permo-Carboniferous temnospondyl Sclerocephalus: Palaeontology, v. 46, p. 1055-1072.

Schoch, R.R., 2009, The evolution of life cycles in early amphibians: Annual Review of Earth and Planetary Sciences, 37, 135-162.

Schoch, R.R., 2012, Character distribution and phylogeny of the dissorophid temnospondyls: Fossil Record, v. 15, p. 119-135.

Schoch, R.R., 2013, The major clades of temnospondyls: an inclusive phylogenetic analysis: Journal of Systematic Palaeontology, v. 11, p. 673-705.

Schoch, R.R., 2014, Amphibian Evolution: The Life of Early Land Vertebrates: New York, Wiley, $280 \mathrm{p}$.

Schoch, R.R., 2018, Osteology of the temnospondyl Neldasaurus and the evolution of basal dvinosaurians: Neues Jahrbuch für Geologie und Paläontologie Abhandlungen, v. 287, p. 1-16.

Schoch, R.R., and Carroll, R.L., 2003, Ontogenetic evidence for the Palaeozoic ancestry of salamanders: Evolution \& Development, v. 5, p. 314-324.

Schoch, R.R., and Fröbisch, N.B., 2006, Metamorphosis and neoteny: alternative pathways in an extinct amphibian clade: Evolution, v. 60, p. 14671475.

Schoch, R.R., and Milner, A.R., 2004, Structure and implications of theories on the origin of lissamphibians, in Arratia, G., Wilson, M.H.V., and Cloutier, R., eds., Recent Advances in the Origin and Early Radiation of Vertebrates: Munich, Pfeil, p. 345-377.

Schoch, R.R., and Milner, A.R., 2008, The intrarelationships and evolutionary history of the temnospondyl family Branchiosauridae: Journal of Systematic Palaeontology, v. 2008, p. 1-23.

Schoch, R.R., and Milner, A.R., 2014, Temnospondyli, in Sues, H.D., ed., Encyclopedia of Paleoherpetology, vol. 3A: Munich, Pfeil, p. 150.

Schoch, R.R., and Rubidge, B.S., 2005, The amphibamid Micropholis stowi from the Lystrosaurus Assemblage Zone of South Africa: Journal of Vertebrate Paleontology, v. 25, p. 502-522.

Schoch, R.R., and Sues, H.D., 2013, A new dissorophid temnospondyl from the Lower Permian of north-central Texas: Comptes Rendus Palevol, v. 12, p. $419-435$

Schoch, R.R., and Witzmann, F., 2009, Osteology and relationships of the temnospondyl genus Sclerocephalus: Zoological Journal of the Linnean Society London, v. 157, p. 135-168.

Schönfeld, G., 1911, Branchiosaurus tener Schönfeld. Ein neuer Stegocephale aus dem Rotliegenden des nordwestlichen Sachsen: Sitzungsberichte und Abhandlungen der naturwissenschaftlichen Gesellschaft Isis, v. 1911, p. $19-43$.

Shishkin, M.A., 1973, The morphology of the early Amphibia and some problems of lower tetrapod evolution: Trudy Paleontologicheskogo Instituta Akademiya Nauk SSSR, v. 137, p. 1-257. [in Russian]

Shishkin, M.A., 1998, Tungussogyrinus - a relict neotenic dissorophoid (Amphibia, Temnospondyli) from the Permo-Triassic of Siberia: Paleontological Journal, v. 32, p. 521-531.

Sigurdsen, T., and Bolt, J.R., 2009, The lissamphibian humerus and elbow joint, and the origins of modern amphibians: Journal of Morphology, v. 270, p. 1443-1453.

Sigurdsen, T., and Bolt, J.R., 2010, The Lower Permian amphibamid Doleserpeton (Temnospondyli: Dissorophoidea), the interrelationships of amphibamids, and the origin of modern amphibians: Journal of Vertebrate Paleontology, v. 30, p. 1360-1377.

Sigurdsen, T., and Green, D.M., 2011, The origin of modern amphibians: a reevaluation: Zoological Journal of the Linnean Society, v. 162, p. 457-469.

Skutschas, P.P., and Gubin, Y.M., 2012, A new salamander from the late Palaeocene-early Eocene of Ukraine: Acta Palaeontologica Polonica, v. 57, p. $135-148$.

Stadtmüller, F., 1936, Kranium und Visceralskelett der Stegocephalen und Amphibien, in Bolk, L., Göppert, E., Kallius, E., and Lubosch, W., eds., Handbuch der Vergleichenden Anatomie der Wirbeltiere: Berlin, Urban und Schwarzenberg, v. 4, p. 501-698.

Steen, M.C., 1931, The British Museum collection of amphibia from the Middle Coal Measures of Linton, Ohio: Proceedings of the Zoological Society London, v. 1930, p. 849-891.

Steen, M.C., 1938, On the fossil Amphibia from the Gas Coal of Nýřany and other deposits in Czechoslovakia: Proceedings of the Zoological Society London, Ser. B, v. 108, p. 205-283.

Trueb, L., and Cloutier, R., 1991, A phylogenetic investigation of the inter- and intrarelationships of the Lissamphibia (Amphibia: Temnospondyli), in Schultze, H.-P., and Trueb, L., eds., Origins of the Higher Groups of Tetrapods: Controversy and Consensus: Ithaca, NY, Comstock Publishing Associates, p. 223-313. 
Vallin, G., and Laurin, M., 2004, Cranial morphology and affinities of Microbrachis, and a reappraisal of the phylogeny and lifestyle of the first amphibians: Journal of Vertebrate Paleontology, v. 24, p. 56-72.

Vasilieva, A.B., and Smirnov, S.V., 2001, Pedicellate teeth and the problems of amphibian phylogeny: Doklady Biological Sciences, v. 376, p. 89-90.

Watson, D.M.S., 1919, The structure, evolution and origin of the Amphibia. The "Orders" Rachitomi and Stereospondyli: Philosophical Transactions of the Royal Society London B. v. 209, p. 1-73.

Watson, D.M.S., 1940, The origin of frogs: Transactions of the Royal Society of Edinburgh, v. 60, p. 195-231.

Werneburg, R., 1986, Die Stegocephalen (Amphibia) der Goldlauterer Schichten (Unterrotliegendes, Perm) des Thuringer Waldes. Teil 1. Apateon flagrifer (Whittard): Freiberger Forschungshefte C, v. 410, p. 88-101.

Werneburg, , R., 1987, Dissorophoiden (Amphibia, Rhachitomi) aus dem Westfal D (Oberkarbon) der CSSR. Branchiosaurus salamandroides Fritsch 1876: Zeitschrift für geologische Wissenschaften, v. 15, p. 681-690

Werneburg, R., 1988, Die Stegocephalen (Amphibia) der Goldlauterer Schichten (Unterrotliegendes, Perm) des Thüringer Waldes. Teil III: Apateon dracyiensis (Boy), Branchierpeton reinholdi $\mathrm{n}$. sp. und andere: Veröffentlichungen Naturkundemuseum Erfurt, v. 1988, p. 80-96.

Werneburg, R., 1989, Labyrinthodontier (Amphibia) aus dem Oberkarbon und Unterperm Mitteleuropas - Systematik, Phylogenie und Biostratigraphie: Freiberger Forschungshefte, v. C 436, p. 7-57.

Werneburg, R., 1990, Dissorophoiden (Amphibia) aus dem Grenzbereich Karbon/Perm der Saale-Senke und des Illfelder Beckens (DDR): Zeitschrift für geologische Wissenschaften, v. 18, p. 665-677.

Werneburg, R., 1991, Die Branchiosaurier aus dem Unterrotliegend des Döhlener Beckens bei Dresden: Veröffentlichungen des Naturhistorischen Museums Schleusingen, v. 6, p. 75-99.

Werneburg, R., 1994, Dissorophoiden (Amphibia, Rhachitomi) aus dem Westfal D (Oberkarbon) von Böhmen. Limnogyrinus elegans (Fritsch 1881) Zeitschrift für geologische Wissenschaften, v. 22, p. 457-467.

Werneburg, R., 2001, Apateon dracyiensis—eine frühe Pionierform der Branchiosaurier aus dem Europäischen Rotliegend, Teil 1: Morphologie: Veröffentlichungen Naturhistorisches Museum Schleusingen, v. 16, p. 17-36.

Werneburg, R., 2009, The Permotriassic branchiosaurid Tungussogyrinus Efremov, 1939 (Temnospondyli, Dissorophoidea)) from Siberia restudied: Fossil Record, v. 12, p. 105-120.
Werneburg, R., 2012, Dissorophoide Amphibien aus dem Westphalian D (Ober-Karbon) von Nýřany in Böhmen (Tschechische Republik)—der Schlüssel zum Verständnis der frühen 'Branchiosaurier': Semana, v. 27, p. $3-50$.

Werneburg, R., Schneider, J.W., and Lucas, S.G., 2013, The dissorophoid Milnererpeton huberi (Temnospondyli) from the Late Pennsylvanian Kinney Brick Quarry in New Mexico restudied-paleontology, paleoenvironment, and age: New Mexico Museum of Natural History and Science Bulletin, v. 59 , p. $349-369$.

Williston, S.W., 1914, Broiliellus, a new genus of amphibian from the Permian of Texas: Journal of Geology, v. 22, p. 364-419.

Witzmann, F., 2013, Phylogenetic patterns of character evolution in the hyobranchial apparatus of early tetrapods: Transactions of the Royal Society of Edinburgh Earth and Environmental Sciences, v. 104, p. 145-167.

Witzmann, F., and Pfretzschner, H.-U., 2003, Larval ontogeny of Micromelerpeton credneri (Temnospondyli, Dissorophoidea): Journal of Vertebrate Paleontology, v. 23, p. 750-768.

Witzmann, F., and Schoch, R.R., 2006, Skeletal development of the temnospondyl Acanthostomatops vorax from the Lower Permian Döhlen Basin of Saxony: Transactions of the Royal Society of Edinburgh Earth Sciences, v. 96, p. $365-185$

Witzmann, F., and Werneburg, I., 2017, The palatal interpterygoid vacuities of temnospondyls and the implications for the associated eye- and jaw musculature: The Anatomical Record, v. 300, p. 1240-1269.

Wyman, J., 1858, On some remains of batrachian reptiles discovered in the Coal Formation of Ohio by Dr J.S. Newberry and C.M. Wheatley: American Journal of Science, v. 25, p. 158-163.

Yates, A.M., and Warren, A.A., 2000, The phylogeny of the 'higher' temnospondyls (Vertebrata: Choanata) and its implications for the monophyly and origins of the Stereospondyli. Zoological Journal of the Linnean Society of London, v. 128, p. 77-121.

Zittel, K.A., 1888, Handbuch der Palaeontologie. 1. Abtheilung: Palaeozoologie. 3rd vol. Vertebrata (Pisces, Amphibia, Reptilia, Aves): Berlin, Oldenbourg, $598 \mathrm{p}$.

Accepted 11 July 2018 